CHRISTIANA MURAKAMI

INDICADORES DE RISCO ASSOCIADOS À PREVALÊNCIA DE EROSÃO DENTÁRIA EM PRÉ-ESCOLARES NO MUNICÍPIO DE DIADEMA, SÃO PAULO 


\title{
Christiana Murakami
}

Indicadores de risco associados à prevalência de erosão dentária em pré-escolares no Município de Diadema, São Paulo

\author{
Dissertação apresentada à Faculdade \\ de Odontologia da Universidade de \\ São Paulo, para obter o título de \\ Mestre, pelo Programa de Pós- \\ Graduação em Ciências Odontológicas \\ Área de Concentração: Odontopediatria \\ Orientador: Prof.Dr. Marcelo \\ J.S.Bönecker
}

São Paulo 
Catalogação-na-Publicação

Serviço de Documentação Odontológica

Faculdade de Odontologia da Universidade de São Paulo

Murakami, Christiana

Indicadores de risco associados à prevalência de erosão dentária em préescolares no Município de Diadema, São Paulo / Christiana Murakami; orientador Marcelo J. S. Bönecker. --- São Paulo, 2009.

$106 \mathrm{p}$.; $30 \mathrm{~cm}$.

Dissertação (Mestrado - Programa de Pós-Graduação em Ciências Odontológicas. Área de Concentração: Odontopediatria) -- Faculdade de Odontologia da Universidade de São Paulo.

1. Erosão dentária - Idade pré-escolar - Indicadores de risco - Diadema (SP) 2. Odontopediatria

AUTORIZO A REPRODUÇÃO E DIVULGAÇÃO TOTAL OU PARCIAL DESTE TRABALHO, POR QUALQUER MEIO CONVENCIONAL OU ELETRÔNICO, PARA FINS DE ESTUDO E PESQUISA, DESDE QUE CITADA A FONTE E COMUNICADA AO AUTOR A REFERÊNCIA DA CITAÇÃO.

São Paulo,

Assinatura:

E-mail: 


\section{FOLHA DE APROVAÇÃO}

Murakami, C. Indicadores de risco associados à prevalência de erosão dentária em pré-escolares no Município de Diadema, São Paulo [Dissertação de Mestrado]. São Paulo: Faculdade de Odontologia da USP; 2009.

São Paulo, / /2009

\section{Banca Examinadora}

1) $\operatorname{Prof}(a) . \operatorname{Dr}(a)$.

Titulação:

Julgamento: Assinatura:

2) $\operatorname{Prof}(\mathrm{a}) . \operatorname{Dr}(\mathrm{a})$.

Titulação:

Julgamento:

Assinatura:

3) $\operatorname{Prof}(a) . \operatorname{Dr}(a)$.

Titulação:

Julgamento: Assinatura: 


\section{DEDICATÓRIA}

Com muito carinho, dedico este trabalho aos meus pais, Edna e Takashi, ao meu irmão, Roberto, e ao meu noivo, Ricardo, que souberam compreender a minha ausência em momentos importantes, sempre me apoiando, me motivando e me inspirando a ser a melhor pessoa que eu posso ser. Muito obrigada! A imensidão do meu amor por vocês não pode ser expressa em palavras! 


\section{AGRADECIMENTOS}

A Deus por ter me dado o presente da vida e por sempre guiar o meu coração e a minha mente na direção certa.

Ao meu pai, Takashi, minha eterna fonte de inspiração e admiração, um exemplo de um ser humano honesto, guerreiro, inteligente e humilde. Obrigada por todas as conversas filosóficas, todos os seus ótimos conselhos e todo 0 seu apoio e seu carinho sempre que eu precisei.

À minha mãe, Edna, meu exemplo de vida, pessoa linda com o coração mais puro que eu já conheci, exemplo de amor incondicional, meu porto seguro, minha fonte inesgotável de forças quando nada parece fazer sentido, esta é a minha mãe. Primeiro, obrigada por me ajudar a organizar o material da pesquisa, por numerar todas as fichas para mim, por me ajudar com os lanches da pesquisa, por me dar forças para terminar de tabular. Depois, obrigada por planejar com tanto carinho cada detalhe da festa do meu casamento que eu não pude ver. Não sei se você sabe o quão grande foi a sua contribuição para que esta dissertação ficasse pronta e para que este sonho se realizasse. Esta conquista é sua também!

Ao meu irmão, Roberto, por todas as brincadeiras e brigas na infância que hoje nos torna inseparáveis. Obrigada por se preocupar tanto comigo, por cuidar de mim como se fosse o meu irmão mais velho, por sempre estar lá quando eu precisei e por ser tão companheiro. Te Amo! 
Ao meu noivo, Ricardo, meu eterno amigo, meu eterno Amor. Depois que você apareceu na minha vida, venho me tornando uma pessoa mais calma, que ouve mais e tenta falar menos, mais segura de mim mesma, mais madura. Obrigada por ser essa pessoa que faz aflorar o que há de melhor em mim. Todo o seu carinho, o seu incentivo, o seu positivismo e a sua ajuda amenizaram as mais árduas jornadas de trabalho e possibilitaram a conquista deste sonho! Mal posso esperar até o dia 09 de janeiro para começarmos a nossa vida juntos e compartilhar o resto da minha vida com você!

Ao Sr.Sato, Da.Noriko e Arthur, pela amizade, apoio, incentivo e conselhos sempre concedidos com muito carinho e por me acolherem em sua família.

À toda a minha família, minhas primas e primos, tias e tios, minha avó Sumiko (in memoriam) e meu avô Masakazu (in memoriam), meus "sobrinhos" queridos, que alegram o meu dia-a-dia e sempre me incentivam e me inspiram a seguir os meus sonhos.

Ao meu orientador, Prof. Marcelo Bönecker, por me ensinar tanto, não só sobre assuntos acadêmicos mas também sobre a vida. Obrigada por estar sempre disposto a me ajudar apesar de estar numa fase de muitas exigências e compromissos em sua vida. Obrigada por me ensinar a conduzir e a redigir um trabalho epidemiológico bem feito. Obrigada por tudo, obrigada mesmo.

À Luciana Butini Oliveira, obrigada pela amizade, pelos conselhos, pelos ensinamentos, pela prontidão e disposição que sempre tem em me ajudar, por tudo o que você contribuiu para este trabalho, sem você, ele não existiria. 
A todos os funcionários da Secretaria Municipal de Saúde de Diadema.

Às todas as crianças que participaram desta pesquisa.

Aos professores da Disciplina de Odontopediatria

Ao Prof. Antonio Carlos Guedes Pinto: Agradeço pelos ensinamentos por trás das conversas na hora do almoço. Por ser um exemplo de determinação, perseverança e garra. Sinto-me privilegiada de poder dizer que convivi ao lado de um dos mais ilustres mestres da Odontologia brasileira.

À Profa. Maria Salete Nahás Pires Corrêa: Desde a época em que a senhora era para mim simplesmente a "tia Salete", a minha dentista, o seu jeito carinhoso, espontâneo e alegre de ser me cativa. A senhora e o meu ortodontista no Japão (Dr.Shimamoto) foram as minhas grandes fontes de inspiração para que eu decidisse pela carreira Odontológica. Após estes 20 anos em que a conheço, dizer que a senhora é um exemplo de odontopediatra, de professora, de mãe, de esposa, de amiga e de ser humano a ser seguido me parece pouco. Não tenho palavras para expressar tamanha admiração, gratidão e amor que sinto por uma pessoa tão importante e que me influenciou e continua influenciando, sempre positivamente, em minha vida! Obrigada por ter chamado a minha atenção para este assunto fascinante que é a erosão dental, 5 anos atrás na minha iniciação científica. Obrigada por sempre me guiar, me ensinar e me incentivar todos estes anos. Em mais de uma maneira, a senhora é responsável pelo sorriso que eu hoje tenho no meu rosto! 
Ao Prof. Fausto Medeiros Mendes: Nossa, que missão difícil the agradecer, são tantos os aspectos pelos quais eu sou grata a você! Melhor ir por partes. Ao Prof.Fausto: obrigada pelos seus inúmeros ensinamentos sobre metodologia científica e bioestatística, obrigada pela oportunidade de aprender a pensar e a argumentar com uma das mais brilhantes mentes da Odontologia, obrigada até mesmo pela rigidez com que me analisou e me questionou todas as vezes em que eu me propus a apresentar algum trabalho, pois hoje eu enxergo o quanto isso me fez crescer profissionalmente. Ao amigo Fausto: obrigada pelas inúmeras risadas, gargalhadas melhor dizendo, que compartilhamos e que aliviam o peso do dia-a-dia e obrigada por sempre me oferecer palavras de incentivo e motivação, me fazendo acreditar mais em mim mesma.

À Profa. Ana Lídia Ciamponi: Como expressar um sentimento tão grande de gratidão, admiração e carinho, que foi crescendo ao longo destes 7 anos em que a conheço, em tão poucas palavras? Às vezes eu me pergunto "será que existe alguma dúvida minha, seja ela profissional ou pessoal, para a qual a Ana não tem a resposta?"! Desde a época da graduação, eu nunca paro de me surpreender com a sua sabedoria, o seu vasto conhecimento, a sua riqueza de espírito - ter alguém como você ao meu lado faz com que tudo pareça mais fácil, até mesmo múltiplas pulpectomias, pinos e coroas num bebê com síndrome de Down! Obrigada pelo seu carinho, pelos seus ensinamentos, pelo seu apoio e pela sua amizade sem os quais eu definitivamente não conseguiria alcançar este sonho que hoje se realiza! 
À Profa. Márcia Turolla Wanderley: Outra professora por quem a minha admiração não pára de crescer desde a época da graduação! A pósgraduação é tão corrida, sinto falta de poder conviver mais de perto, pois sei que eu ainda tenho muito a aprender com você. Obrigada por ter me ensinado a fazer uma "endo, pino e coroa" bem feita na especialização, obrigada pela convivência e pelos bons momentos compartilhados no mestrado, obrigada por acreditar em mim e sempre me apoiar e obrigada por sempre se dispor a tirar as minhas dúvidas sobre os casos difíceis de traumatismo que aparecem!

À Profa. Daniela Prócida Raggio: Existem pessoas que, quando entram numa sala, iluminam o ambiente - a Dani é uma delas. Obrigada pela amizade e pelo carinho com os quais você sempre me trata. Os seus valiosos conselhos e as divertidas brincadeiras me ajudaram a chegar até esta conquista!

À Profa. Mariana Minatel Braga: Incrível como é possível conviver com uma pessoa por tanto tempo, porque a gente se conhece de vista desde a graduação, e não saber como aquela pessoa é especial! Saiba que eu a admiro muito por todo o conhecimento que você tem, pelas conquistas bem merecidas e pelo seu jeito calmo e amigável de ser. Fiquei muito feliz em poder conhecê-la melhor durante o meu mestrado e muito obrigada pela sua amizade e apoio.

À Profa. Claudia Perez Trindade: Pessoa querida e mestre ilustre, sem a qual a minha formação em Odontologia nunca estaria completa. São poucos os professores cujos ensinamentos você guarda para o resto da vida e os seus, Claudinha, eu guardo e sempre guardarei no peito. Apesar de você não ser 
professora da pós, eu continuo aprendendo muito com você, com as nossas conversas de corredor. Acredito que um dos momentos em que eu mais aprendi durante o mestrado foi ficando como sua auxiliar na clínica do noturno! Muito obrigada por tudo!

Ao Prof. José Carlos Pettorossi Imparato: Sua presença como professor é tão marcante, que ainda me lembro do primeiro curso seu que eu assisti, no CIOSP de 2003, como se fosse ontem. Me lembro da sala, das cadeiras e de como as pessoas da platéia te olhavam com admiração e curiosidade! Professor homenageado da minha turma de graduação, querido por todos! Apesar de não termos tido a chance de conviver muito proximamente nos meus anos de mestrado, espero poder aproveitar mais os seus ensinamentos durante o doutorado.

À Profa. Célia Regina Martins Delgado Rodrigues (in memoriam): Que saudades... Gostaria de deixar aqui o mesmo que a senhora me ouviu dizer na minha monografia: "creio que pessoas como a senhora são as responsáveis por todas as boas mudanças que ocorrem no mundo pois passam por ele plantando não só sementes de conhecimento mas também de carinho, dedicação e paciência". Obrigada por ter me ensinado, além de todos os conhecimentos científicos, o real valor e a real importância dos diferentes aspectos da vida.

\section{Aos amigos do curso de pós-graduação:}

Jenny: "personal publicator" - hehe! Fico muito feliz de ter tido a chance te conhecer melhor e de descobrir em você uma ótima amiga! Obrigada por todas 
as nossas longas conversas e pela companhia alegre de sempre. Ainda bem que temos mais 3 anos antes de você pensar em voltar para o Peru, vamos curtir bastante né?

Jana: você é uma pessoa muito meiga e calma, que eu adoro ter por perto. Às vezes a correria do dia-a-dia não permite que a gente converse tanto mas os poucos momentos que compartilhamos são demais!

Tati: admiro a organização e a garra que você tem. Quando você disse que o ano que vem trará novas energias, parece que você tinha adivinhado né? Saiba que torço por você e que pode contar comigo ok?

Paula: amiga querida do coração. Desde o primeiro dia da especialização, já sabia que seríamos amigas. Entramos juntas na pós, enfrentamos juntas os desafios, aproveitamos juntas os bons momentos! Saiba que eu fico muito orgulhosa de ser amiga da "Celiberti P" e que te admiro muito! Por favor fique por perto ano que vem também hein?! Ainda temos muito o que fazer e curtir juntas!

Thiago: "a USP todinha" pegou né?! Thanks for all the good times we shared! Obrigada por tornar o nosso dia-a-dia mais divertido com as suas brincadeiras! Boa sorte ano que vem na Suíça!

Fabi: exemplo de perseverança, de que quando a gente quer mesmo alguma coisa, a gente faz! Muito obrigada pela amizade, pelo carinho e pelas conversas que eu adoro!

Babou: pessoa meiga e preocupada com todos. Não sei como você consegue fazer todas as coisas que faz e tão bem, algum dia eu quero ser que nem você Ba! Te admiro muito como profissional e te adoro como amiga. 
Lucila: "apleca", eu lembro e fico rindo sozinha! Minha companheira de bancada durante as aulas de tele. É muito bom ter uma pessoa tranqüila, experiente e divertida como você por perto! Te admiro muito!

Isa: gosto muito das nossas conversas! Admirável como você consegue administrar bem a pós, o filho pequeno e o consultório! Pena que não sobra muito tempo para você ficar com a gente papeando no departamento né?

Cássio: por todos os ensinamentos de teleodontologia e de cirurgia, pela amizade e por estar sempre disposto a ajudar o próximo

Aos amigos que foram examinadores neste trabalho: Fe Nahás, José Paulo, Renata Egydio, Veridiana, Karin, Rejane, Gabi, Tuca, Paula, Jenny, Babou, Jana, Lucila, Thiago, Tati - Muitíssimo obrigada por terem acordado cedo, estado às 6:30 na FOUSP num pleno sábado e ter passado o dia inteiro trabalhando na Campanha de vacinação. Se algum de vocês faltasse, este estudo simplesmente não seria possível. Fiquei muito emocionada com a demonstração de amizade que recebi naquele dia e serei eternamente grata a vocês por isso!

Aos colegas dos cursos "antigos" e do curso "novo" de pós-graduação em Odontopediatria: Fe Nahás: amiga querida, obrigada por todo o seu apoio e por sempre torcer por mim, não sei se você sabe o quanto isso me ajuda e me ajudou a chegar até aqui; Adri Ortega: o seu agradecimento está junto com o GEAPE! Fe Morais: obrigada por ter me ensinado muitas coisas sobre estudos in situ; Adri Tashima: amiga que eu adoro, obrigada pelos conselhos; Ricardo Navarro, Thiago Ardenghi, Franscisco, Lu Sanglard, Dani Cerqueira, Marcela nunca vou me esquecer. Aos colegas do curso novo: 
sejam bem-vindos, vamos tornar os próximos anos inesquecíveis; em especial: Dani Bittar: amiga querida de anos! Fiquei muito feliz em saber que vamos passar mais tempos juntas agora!

Aos funcionários da disciplina: Júlio, Fátima, Marize: não tenho palavras para agradecer a ajuda de vocês, obrigada pela amizade e pela agradável convivência. O que seria de mim sem os cuidados da Marize, o bolo da Fátima e as brincadeiras do Júlio?!

\section{Ao GEAPE:}

Profa. Adriana Ortega: Impossível expressar em tão pouco espaço o quanto eu te admiro, te adoro e sou grata por Deus ter colocado uma pessoa tão especial em meu caminho. Você é uma verdadeira "role model" para mim, pessoa em que eu me espelho, que eu espero algum dia poder ser metade tão boa quanto! Obrigada por ser minha amiga e minha constante fonte de inspiração!

Profa. Stella Vieira: Quem vê o seu jeito quietinho e humilde de ser, nem imagina o mundo de conhecimentos que a Stella armazena e tem para compartilhar com todos! Amiga querida, companheira de vários anos de GEAPE, professora admirada e muito respeitada. Obrigada pelos bons momentos compartilhados e pelos seus ensinamentos!

Às colegas do GEAPE: em especial para Viviane Rossier, Dani Bittar, Thais Matsumoto e Carol - obrigada pela convivência tão agradável de tantos anos que me faz sentir falta de vocês, como se eu estivesse longe da minha família mesmo, quando tenho outros compromissos da pós.

Aos pacientes do GEAPE: obrigada por me ensinar o quanto a vida é bela e que devemos sempre olhar o lado positivo das coisas e das pessoas; cuidar de 
vocês para mim é uma troca pois vocês também cuidam de mim, às vezes sem nem mesmo saber

Às funcionárias do CAPE: Jeane, Cris, Bel, Marlene, Gil e Sandra pela qualidade do serviço prestado e pela amizade

Ao Prof. Matsuyoshi Mori e à Profa. Aiko Mori: pela amizade e por sempre me incentivarem a seguir me qualificando e aprimorando os meus conhecimentos

Ao Prof. Leopoldo Antunes: pelos ensinamentos e por estar sempre disponível para esclarecer dúvidas com um sorriso no rosto.

Aos alunos do curso de Graduação: por renovarem as minhas energias em busca de novos conhecimentos e descobertas

Ao CNPq: pela bolsa de estudo concedida durante o curso.

A todos que de alguma maneira contribuíram para a realização deste trabalho! 


\section{EPÍGRAFE}

"Live as if you were to die tomorrow. Learn as

if you were to live forever" - Mahatma Gandhi 
Murakami, C. Indicadores de risco associados à prevalência de erosão dentária em pré-escolares no Município de Diadema, São Paulo [Dissertação de Mestrado]. São Paulo: Faculdade de Odontologia da USP; 2009.

\section{RESUMO}

O presente estudo teve como objetivos avaliar a prevalência, a distribuição e o grau de acometimento das lesões de erosão dentária em crianças de 36 a 59 meses de idade no município de Diadema, São Paulo. Em posse desses dados, também se objetivou investigar os indicadores de risco socioeconômicos, ambientais, nutricionais, comportamentais e de características da criança associados à prevalência de erosão dentária. Cirurgiões dentistas treinados e calibrados (Kappa interexaminadores $=0,77$ para erosão e 0,83 para cárie) examinaram 967 crianças em Unidades Básicas de Saúde (UBS) do município de Diadema durante a primeira etapa da Campanha Nacional de Multivacinação Infantil em Junho de 2008. Para avaliar a erosão dentária, utilizou-se o índice de O'Brien (1994) modificado, para as lesões de cárie dentária o índice de Knutson (1944) e para o estado nutricional

o padrão de referência da OMS (WHO Child Growth Standards, 2006). A ocorrência de fatores associados foi investigada por meio de um questionário elaborado especificamente para esta pesquisa, com base na literatura. Análises de regressão logística univariada e múltipla com modelo hierárquico $(p<0,05)$ foram realizadas. A prevalência de erosão dentária foi de $51,6 \%$, sendo a maioria das lesões encontradas em esmalte (82,5\%). As lesões erosivas foram mais prevalentes em incisivos superiores do que em molares inferiores e houve uma tendência de bilateralidade no padrão de acometimento. 
O modelo logístico hierárquico final revelou associação significativa entre a prevalência de erosão dentária e as variáveis comportamentais de consumo de refrigerantes duas vezes ao dia $(O R=0,78$; IC 95\%: 0,43-1,40; $p=0,043)$ e três ou mais vezes ao dia (OR=1,74; IC 95\%; 1,02-2,99; $p=0,023)$, consumo de sucos nos últimos dois dias prévios ao estudo (OR=1,55; IC95\%; 1,11-2,16; $p=0,009)$ e a presença de refluxo gastroesofágico relatado $(\mathrm{OR}=2,06$; IC95\%; $1,24-3,41 ; p=0,005)$. Dentre as variáveis relacionadas com as características da criança apenas o aumento da idade foi significativo (OR=1,48; IC $95 \%$; 1,151,92; $p=0,003)$. Não houve associação significativa entre a prevalência de erosão dentária e variáveis socioeconômicas, ambientais e o estado nutricional. Portanto, pode-se inferir que, nesta população, a prevalência de erosão dentária foi alta e estava associada à ingestão frequente de bebidas ácidas, à presença de refluxo gastroesofágico relatado e à idade da criança.

Palavras-Chave: Epidemiologia - Prevalência - Erosão Dentária 
Murakami, C. Risk indicators associated to the prevalence of dental erosion in preschool children in Diadema, São Paulo [Dissertação de Mestrado] São Paulo: Faculdade de Odontologia da USP; 2009.

\section{ABSTRACT}

The aim of the present study was to assess the prevalence, distribution and severity of erosive lesions in a sample of 36 to 59 -month-old children in the city of Diadema, São Paulo. Moreover, the association between dental erosion prevalence and socioeconomic, environmental, nutritional, behavioral, and child characteristics variables was investigated. Trained and calibrated dentists (interexaminer Kappa $=0.77$ for dental erosion and interexaminer Kappa $=0.83$ for dental caries) examined 967 children in the Basic Health Units (BHU) of the city of Diadema during the first stage of the National Children's Vaccination Day in 2008. Dental erosion, dental caries and nutritional status were assessed through the use of a modified version of the O'Brien (1994) index, Knutson (1944) index, and the WHO Child Growth Standards (2006), respectively. Variables associated to the prevalence of dental erosion were investigated using a questionnaire that was specifically developed for the present research, based on the literature. Statistical analysis was conducted through univariate and multivariate regressions based on a hierarchical model $(p<0.05)$. Dental erosion prevalence was of $51.6 \%$ and most of the erosive lesions observed were confined to the enamel $(82,5 \%)$. Erosive lesions were more prevalent in the upper incisors than in lower molars and a symmetrical pattern of distribution was noted. The final hierarchical logistic model revealed a significant 
association between dental erosion prevalence and the consumption of soft drinks twice $(\mathrm{OR}=0.78 ; \mathrm{Cl} 95 \%: 0.43-1.40 ; \mathrm{p}=0.043)$ or three or more $(\mathrm{OR}=1.74 ; \mathrm{Cl} 95 \% ; 1.02-2.99 ; \mathrm{p}=0.023)$ times a day, juice intake on the last two days before the study (OR=1.55; $\mathrm{Cl} 95 \% ; 1.11-2.16 ; \mathrm{p}=0.009)$, the presence of frequent reported gastroesophageal reflux (OR=2.06; Cl 95\%; 1.24-3.41; $\mathrm{p}=0.005)$ and increasing age $(\mathrm{OR}=1.48 ; \mathrm{Cl} 95 \% ; 1.15-1.92 ; \mathrm{p}=0.003)$. No statistically significant associations were found between dental erosion prevalence and socioeconomic, environmental or nutritional variables. In conclusion, a high prevalence of dental erosion was found in this population of preschool children, which was associated with frequent consumption of acidic beverages, frequent episodes of reported gastroesophageal reflux, and an increase in age. 


\section{LISTA DE ABREVIATURAS E SIGLAS}

ACS Agente Comunitário de Saúde

AE Auxiliar de Enfermagem

ASB $\quad$ Auxiliar de Saúde Bucal

DRGE Doença do Refluxo Gastroesofágico

IBGE Instituto Brasileiro de Geografia e Estatística

IC Intervalo de Confiança

IDH Índice de Desenvolvimento Humano

IDI Índice de Desenvolvimento Infantil

n valor absoluto

OMS Organização Mundial de Saúde

p valor teste estatístico, indicador do nível de significância

RGR Refluxo Gastroesofágico Relatado

SEADE Sistema Estadual de Análise de Dados

SM Salário Mínimo

UBS Unidade Básica de Saúde

WHO World Health Organization 


\section{SUMÁRIO}

p.

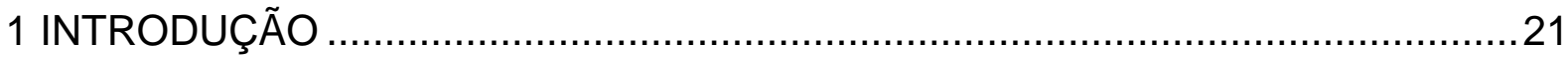

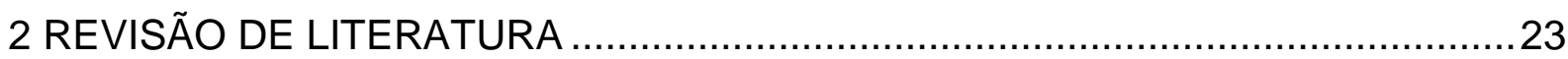

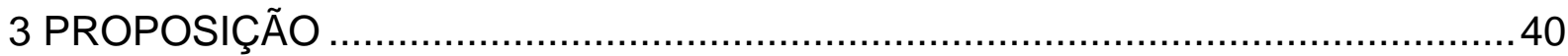

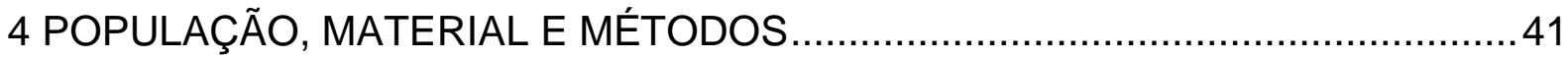

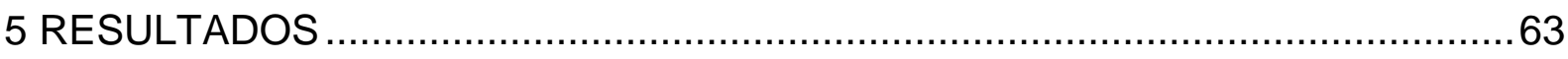

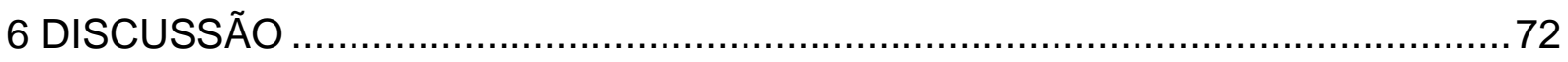

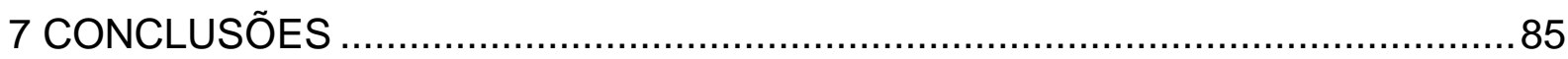

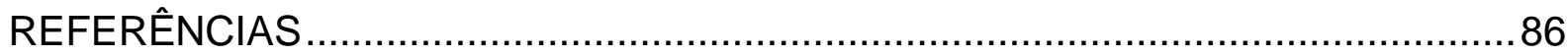

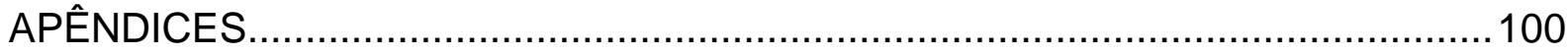

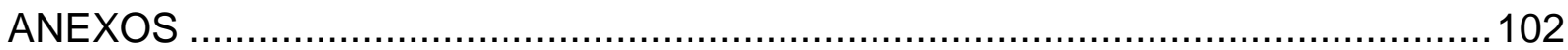




\section{INTRODUÇÃO}

Ultimamente, o aumento da prevalência de erosão dentária tem atraído a atenção de clínicos e pesquisadores da área de Odontologia ao redor do mundo. Erosão dentária é a perda superficial de tecido dental duro ocasionada por um processo químico que não envolve bactérias (PINDBORG, 1970).

Estudos sobre a prevalência de erosão dentária em crianças pré-escolares ainda são escassos e apresentam resultados divergentes, variando entre 5,7\% (LUO et al., 2005) 95\% (AL-MAJED; MAGUIRE; MURRAY, 2002). Um fato alarmante é que a maioria dos estudos indica que $30 \%$ ou mais das crianças nesta faixa etária já apresentam desgaste patológico por erosão dentária (AL-MALIK; HOLT; BEDI, 2001; JONES; NUNN, 1995; MILLWARD; SHAW; SMITH, 1994; MILLWARD et al., 1994; WALKER et al., 2000; WIEGAND et al., 2006). Porém, no Brasil, ainda não existem dados sobre a prevalência desta patologia em pré-escolares.

Alguns estudos epidemiológicos já demonstraram claramente a associação de problemas de saúde bucal a fatores socioeconômicos e ambientais e ao estado nutricional em pré-escolares (FREIRE, 2004; OHSUKA et al., 2009; OLIVEIRA, 2006). No entanto, na literatura Odontológica atual, raros são os trabalhos que investigaram a relação entre a erosão e estes fatores.

Por outro lado, a mesma literatura relata evidência consistente de que a erosão dentária é causada por ácidos que podem ser intrínsecos ou extrínsecos (GANDARA; TRUELOVE, 1999) e que estão associados ao comportamento da criança. 
Frente ao exposto, o presente estudo almeja contribuir com o conhecimento existente sobre a prevalência, a distribuição e a gravidade de lesões erosivas em pré-escolares e sobre a associação desta prevalência com variáveis socioeconômicas, ambientais, nutricionais, comportamentais e relacionadas a características da criança.

Em posse destas informações, ações educativas e de mínima intervenção com enfoque populacional poderão ser implementadas para que este problema de saúde bucal possa ser prevenido e o processo de doença paralisado. 


\section{REVISÃO DA LITERATURA}

Ao longo de suas vidas, todos os indivíduos sofrem algum grau de desgaste dental. Normalmente, este desgaste é uma combinação entre os fenômenos de atrição, abrasão e erosão (GANDARA; TRUELOVE, 1999; IMFELD, 1996; MAHONEY; KILPATRICK, 2003; MILLWARD; SHAW; SMITH, 1994), podendo ser fisiológico (BARTLETT; DUGMORE, 2008). Porém, quando o grau de desgaste presente é demasiadamente severo para a idade do indivíduo, ele passa a ser patológico (YOUNG et al., 2008). De fato, os diversos tipos de desgaste dental, incluindo a erosão, estão listados no International Classification of Diseases, assim definindo-os como patologias (GANSS, 2008; WHO, 2007).

Quando há clara indicação de que o fator etiológico do desgaste é o contato de soluções ácidas com a superfície dos dentes, o fenômeno é denominado de erosão dentária. A definição clínica de erosão dentária é de perda crônica e irreversível de tecido dental duro ocasionada por um processo químico de dissolução ácida ou quelação de cálcio que não envolve bactérias (DEERY et al., 2000; ECCLES, 1979; IMFELD, 1996; PINDBORG,1970).

Por caracterizar um processo cumulativo, ao longo dos anos, o desgaste patológico por erosão dentária pode acarretar em perdas severas de esmalte e dentina que exigem reabilitações extensas e de custo elevado (LUSSI; JAEGGI, 2006). Além disso, crianças com lesões erosivas na dentição decídua possuem um maior risco de apresentarem erosão na dentição permanente (GANSS; KLIMEK; GIESE, 2001). Portanto, o estudo da prevalência de erosão dentária e a investigação de variáveis associadas a esta patologia na dentição decídua é 
importante para viabilizar a instituição precoce de medidas preventivas (JAEGGl; LUSSI, 2006).

\subsection{Critérios de diagnóstico e índices utilizados para a classificação de lesões erosivas}

Em 1995, ocorreu o Workshop on Dental Erosion na Bélgica, onde foi levantada a necessidade de se estabelecer um índice adequado para avaliar a presença de erosão dentária. Contudo, mais de dez anos depois, a comparação direta dos resultados de estudos epidemiológicos sobre a prevalência de erosão dentária ainda é prejudicada pela inexistência de um índice universalmente aceito para a avaliação de lesões erosivas (YOUNG et al., 2008). Considerando este fato, Bardsley (2008) delineou as características ideais de um índice para classificar a erosão dentária, incluindo: ser de simples compreensão e uso; ter claros critérios de classificação; ser reprodutível; ser útil para pesquisas sobre prevalência, etiologia e monitoramento da condição; e ser essencialmente uma ferramenta clínica e epidemiológica.

Um dos primeiros índices propostos para classificar lesões erosivas foi desenvolvido por Eccles (1979). Trata-se de um índice para classificar a gravidade e a localização das lesões erosivas, contendo uma descrição qualitativa bastante detalhada das características das lesões. Pode ser considerado como um índice cardinal, a partir do qual outros índices foram desenvolvidos. Porém, este índice não 
é de fácil compreensão e uso por possuir extensas descrições das características a serem verificadas, que são distintas para cada superfície dental avaliada.

O Tooth Wear Index (TWI) criado por Smith e Knight (1984) atribui um escore para cada uma das superfícies dentárias desgastadas, independentemente do desgaste ter sido causado por atrição, abrasão ou erosão. O TWI é um índice que não requer que seja feito o diagnóstico diferencial entre os tipos de desgaste dentários (BARDSLEY, 2008). No entanto, ele não é um índice indicado quando o objetivo do estudo é investigar especificamente a prevalência de erosão dentária (GANSS, 2008). Além disso, alguns estudos têm relatado dificuldades com relação ao longo tempo necessário para se aplicar o TWI na dentição toda (BARDSLEY, 2008).

Recentemente, em virtude da necessidade de se eleger um índice para a erosão dentária que fosse universalmente aceito, os autores Bartlett, Ganss e Lussi (2008) criaram um índice chamado BEWE (Basic Erosive Wear Examination) (Anexo A) que foi formulado em um workshop que ocorreu em Basle (Suíça) em 2007 (YOUNG et al., 2008). O BEWE preconiza a soma dos escores mais altos de cada sextante da cavidade oral para se determinar o nível de risco, que por sua vez corresponde aos procedimentos clínicos indicados para o manejo do quadro de erosão do paciente. A grande desvantagem do BEWE é que, sempre que se soma ou se tira a média somente dos escores mais altos de cada sextante, muitos dados são perdidos (BARDSLEY, 2008). Por exemplo, dados sobre a distribuição e a gravidade das lesões erosivas por dente não são adequadamente coletados quando o BEWE é utilizado. 
Além disso, a descrição do BEWE para a profundidade da lesão erosiva não é completa e nem clara. Para exemplificar, considerando-se uma lesão erosiva inicial com perda de tecido duro em esmalte acometendo mais da metade da superfície, como comumente encontrada nas faces dentais lisas, esta receberia o escore mais alto do BEWE (escore 3). Desta maneira, a mesma não seria distinguida de uma lesão avançada, já com proximidade pulpar, que também apresenta "perda de tecido duro em mais da metade da área da superfície" (escore 3), como descrito por Bartlett, Ganss e Lussi (2008).

Inúmeros outros índices podem ser encontrados na literatura (BARDSLEY, 2008). Dentre estes, Berg-Beckhoff, Kutschmann e Bardhle (2008) verificaram que o índice de O'Brien (1994) (Anexo B), aplicado no levantamento de saúde bucal infantil no Reino Unido, foi o mais frequentemente utilizado em estudos sobre a prevalência de erosão dentária em crianças. É um índice claro e completo uma vez que classifica separadamente a profundidade e a área da lesão erosiva, sendo que os escores de cada um de seus critérios de diagnóstico são aplicáveis a qualquer superfície dental.

Para a classificação da profundidade de acordo com o índice de O'Brien (1994), a superfície dental erodida pode receber escore 1, 2 ou 3 referente à lesão em esmalte, em dentina ou com exposição pulpar, respectivamente (Anexo B). A classificação da área da lesão deve ser feita sempre com base no pior escore de profundidade encontrado e esta se divide em escores 1, 2 ou 3 referente à lesão com menos de $1 / 3$ da área, até $2 / 3$ da área e mais de $2 / 3$ da área da superfície dental comprometida, respectivamente. Para ambos os critérios de profundidade e área da lesão, o escore 0 indica superfície hígida e o escore 9 indica uma superfície onde a avaliação não pôde ser realizada. 
Adicionalmente, o índice de O'Brien (1994) se enquadra na maioria das características ideais de um índice para erosão dentária descritas por Bardsley (2008) na medida em que é de simples compreensão e uso, tem critérios de classificação bem definidos qualitativamente sem serem extensivos, é útil em pesquisas sobre prevalência, etiologia e monitoramento da erosão dentária e serve essencialmente como uma ferramenta clínica e epidemiológica. Com relação à reprodutibilidade deste índice, apesar de o mesmo ainda não ter sido validado, estudos que utilizaram este instrumento relatam ter obtido bons índices de concordância interexaminadores.

\subsection{Prevalência, distribuição e gravidade das lesões erosivas}

Publicações recentes evidenciam que a erosão dentária é um problema que acomete particularmente populações de crianças e adolescentes, constituindo nestas o principal componente do desgaste dental patológico (AL-DLAIGAN; SHAW; SMITH, 2001; DESHPANDE; HUGAR, 2004). Entretanto, existem poucos estudos epidemiológicos internacionais e nenhum estudo nacional sobre a prevalência de erosão dentária, em crianças na faixa etária pré-escolar.

$\mathrm{Na}$ literatura, até o presente momento, há quinze estudos (Anexo C) que investigaram a prevalência desta patologia em amostras de crianças que incluíam pré-escolares. Dentre estes, se forem selecionados somente os que analisaram 
amostras de crianças com idades condizentes com as do presente trabalho, entre 3 e 4 anos, foi encontrado um total de oito estudos (Tabela 2.1). A prevalência de erosão dentária nesta faixa etária variou entre 5,7\% (LUO et al., 2005) e 95\% (ALMAJED; MAGUIRE; MURRAY, 2002), sendo que a maioria dos estudos reportou uma prevalência maior do que aproximadamente 30\% (AL-MALIK; HOLT; BEDI, 2001; JONES; NUNN, 1995; MILLWARD; SHAW; SMITH, 1994; MILLWARD et al., 1994; WALKER et al., 2000; WIEGAND et al., 2006).

Tabela 2.1 - Estudos sobre a prevalência de erosão dentária em pré-escolares na faixa etária de 3 e 4 anos

\begin{tabular}{|l|l|c|c|c|c|}
\hline ANO & \multicolumn{1}{|c|}{ AUTORES } & PAís & AMOSTRA & $\begin{array}{c}\text { FAIXA } \\
\text { ETÁRIA } \\
\text { (anos) }\end{array}$ & PREVALÊNCIA (\%) \\
\hline 1994 & Millward et al.(a) & Inglaterra & 178 & $4-5$ & 50 \\
\hline 1995 & Hinds e Gregory & Reino Unido & 1451 & $1,5-4,5$ & 19 \\
\hline 1995 & Jones e Nunn & Reino Unido & 135 & 3 & 29 \\
\hline 2000 & Walker et al. & Reino Unido & 1.726 & $4-6$ & 65 \\
\hline 2001 & Al-Malik et al. & Arábia Saudita & 987 & $2-5$ & 31 \\
\hline 2005 & Luo et al. & China & 1949 & $3-5$ & 5,7 \\
\hline 2006 & Wiegand et al. & Alemanha & 463 & $2-7$ & $32 ; 13.2$-dentina \\
\hline
\end{tabular}

Em 2003, Nunn et al.(2003) analisaram dados provenientes de três levantamentos nacionais britânicos sobre a prevalência de erosão dentária em crianças, conduzidos nos anos de 1993 (UK National Children's Dental Health Survey - NCDHS) e 1996-1997 (National Diet and Nutrition Survey-NDNS). Todos estes levantamentos utilizaram o índice de O’Brien (1994) para classificar lesões erosivas, facilitando a comparação entre eles. Os resultados mostraram que houve uma tendência de aumento da prevalência de erosão dentária em crianças entre 4 a 6 anos de idade no decorrer dos anos, pois o índice encontrado no NCDHS em 1993 foi de $18 \%$ enquanto que no NDNS de $1996-97$ foi de $38 \%$. 
Com relação à distribuição das lesões erosivas na dentição decídua de préescolares com menos de 4 anos de idade, Millward, SHAW; SMITH (1994), Millward et al. (1994) e Wiegand et al. (2006) verificaram uma maior prevalência de erosão nos incisivos superiores. Os outros trabalhos em pré-escolares não investigaram a distribuição de lesões. Porém, estudos em crianças maiores de 4 anos de idade na dentição decídua indicaram um padrão de distribuição semelhante, com uma maior prevalência de erosão dentária nos incisivos superiores (DESHPANDE; HUGAR, 2004; KAZOULLIS et al., 2007). Além disso, as lesões erosivas em incisivos superiores decíduos são mais frequentes na superfície palatina do que na vestibular (CHADWICK; PENDRY, 2003; DESHPANDE; HUGAR, 2004; JONES; NUNN, 1995; MILLWARD; SHAW; SMITH, 1994; NUNN et al., 2003; O'BRIEN, 1994).

Grande parte das lesões erosivas encontradas em crianças menores de 4 anos de idade era de gravidade leve, estando ainda em esmalte (AL-MALIK; HOLT; BEDI, 2001; HINDS; GREGORY, 1995; JONES; NUNN,1995; MILLWARD; SHAW; SMITH, 1994; MILLWARD et al., 1994; WIEGAND et al., 2006). Estudos sobre a dentição decídua de crianças com mais de 4 anos de idade também revelaram uma maior prevalência de lesões erosivas em esmalte (AL-MAJED; MAGUIRE; MURRAY, 2002; DESHPANDE; HUGAR, 2004; HARDING et al., 2003; RIOS et al., 2007). Adicionalmente, com relação à área de acometimento pela lesão erosiva, lesões ocupando mais de 2/3 da superfície são as mais frequentes (CHADWICK; PENDRY, 2003). 


\subsection{Variáveis associadas à ocorrência de erosão dentária}

Desde o século XIX, numerosos estudos (AL-MAJED; MAGUIRE; MURRAY, 2002; ÀRNADÓTTIR et al., 2002; DARBY, 1892; ECCLES 1979; HARDING et al., 2003; JOHANSSON; LINGSTRÖM; BIRKHED, 2002; LUO et al., 2005; MAHONEY; KILPATRICK, 2003; MILOSEVIC; YOUNG; LENNON, 1994; PERES et al., 2005; WIEGAND et al., 2006) têm sido realizados com o intuito de determinar a prevalência da erosão dentária e identificar os seus fatores etiológicos. A partir destes estudos, concluiu-se que a erosão dentária é uma doença multifatorial, podendo possuir etiologia intrínseca ou extrínseca, intimamente associada ao comportamento do paciente.

Os fatores etiológicos extrínsecos da erosão dentária são constituídos por soluções ácidas provenientes de diversas fontes como: ácidos da dieta (bebidas e alimentos) (GANDARA; TRUELOVE, 1999), medicamentos de uso crônico (LINNETT e SEOW, 2001), produtos de higiene oral (MAHONEY; KILPATRICK, 2003), fumaças industriais (ECCLES, 1979), água de piscina incorretamente tratada (IMFELD, 1996) e drogas ilícitas (MAHONEY; KILPATRICK, 2003). Já o fator etiológico intrínseco da erosão dentária é o ácido gástrico que é levado à cavidade oral e estabelece contato com os dentes quando ocorre refluxo gastresofágico, regurgitação, vômito ou ruminação (ECCLES, 1979; GANDARA; TRUELOVE, 1999; IMFELD, 1996; JÄRVINEN; RYTÖMAA; MEURMAN, 1992; LUO et al., 2005).

Em 2006, Lussi salientou que a compreensão completa da etiologia da erosão dentária vai além dos fatores causais diretos extrínsecos e intrínsecos. De acordo 
com o mesmo, o desenvolvimento das lesões erosivas depende não só da interação entre fatores comportamentais, biológicos e químicos mas também da interação destes com o nível socioeconômico, a educação, o conhecimento e a saúde geral do paciente. Nunn et al. (2003) também enfatizaram que o conceito de que a etiologia da erosão dentária está ligada somente à exposição dos dentes a ácidos é simplista e que outros fatores como socioeconômicos, culturais e geográficos podem ser relevantes.

\subsubsection{Variáveis socioeconômicas}

A maioria dos trabalhos epidemiológicos encontrados na literatura se concentra em estudar os fatores de risco biológicos. Porém, sabe-se que o estudo dos fatores sociais é fundamental para a compreensão do processo saúde/doença (OLIVEIRA, 2006). De uma maneira geral, indivíduos pertencentes a estratos socioeconômicos mais baixos possuem menor acesso a informações sobre cuidados com a saúde bucal e ao tratamento odontológico, podendo estar mais predispostos à ocorrência de doenças orais (SABBAH et al., 2009; SANDERS et al., 2006).

Referente à influência do nível socioeconômico na prevalência da erosão dentária em crianças, alguns autores verificaram uma associação com níveis socioeconômicos mais baixos (HARDING et al., 2003; JONES; NUNN, 1995; KAZOULLIS et al., 2007). Apesar destes autores não oferecerem explicações para esta associação, de maneira geral, sabe-se que o baixo nível socioeconômico está 
associado ao maior risco de se desenvolver patologias orais (SABBAH et al., 2009; SANDERS et al., 2006). Por outro lado, Millward, SHAW; SMITH (1994) observaram que a prevalência de erosão dentária foi maior em crianças de nível socioeconômico mais alto. Estes resultados podem ser atribuídos a padrões diferentes de dieta (com maior acesso ao consumo de bebidas industrializadas) e hábitos de higiene oral (maior frequencia de escovação) (MILLWARD; SHAW; SMITH, 1994). Luo et al. (2005) também relataram uma associação entre a maior prevalência de erosão dentária e níveis socioeconômicos altos na China.

Existem também estudos que não encontraram correlação entre a prevalência de erosão dentária e a classe socioeconômica (AL-MAJED; MAGUIRE; MURRAY, 2002; AL-MALIK; HOLT; BEDI, 2001; HINDS; GREGORY, 1995; WALKER et al., 2000).

\subsubsection{Variáveis ambientais}

No contexto da promoção de saúde para crianças, ambientes saudáveis referem-se aos aspectos físicos e sociais que as cercam (MOYSÉS; RODRIGUES, 2004), dentre os quais se incluem: a aglomeração domiciliar, o tipo de moradia e o número de filhos que os pais da criança têm. Sabe-se que fatores ambientais estão associados à prevalência de outras patologias orais como a cárie dentária (BÖNECKER, 2005; OHSUKA et al., 2009; RAMOS-GOMEZ et al., 2002) e o traumatismo dentário (GLENDOR, 2009; WASMER; POHL; FILIPPI, 2008). Porém, 
com relação à erosão dentária, ainda não há estudos na literatura investigando esta associação.

\subsubsection{Variáveis nutricionais}

O estado nutricional de uma população é resultante da disponibilidade dos alimentos no domicílio e das condições ambientais e econômicas (MONTEIRO; CONDE, 2000). De acordo com Freire (2004), a nutrição e a dieta podem afetar a saúde bucal em dois períodos distintos: pré-eruptivo e pós-eruptivo. No período préeruptivo, a desnutrição pode resultar em defeitos na estrutura dental, alteração na cronologia de erupção e na formação de glândulas salivares. Dentre os efeitos póseruptivos dos hábitos alimentares inadequados, pode-se citar a ocorrência de ambas: a erosão dentária e a cárie dentária (FREIRE, 2004). Assim, o estado nutricional da criança pode estar associado à ocorrência de erosão dentária.

Apesar disso, até o presente momento, somente um estudo (MCGUIRE et al., 2009) investigou a associação entre a prevalência de erosão dentária e o estado nutricional mas não em pré-escolares como no atual trabalho. McGuire et al. (2009) utilizaram dados secundários coletados durante o Levantamento Nacional de Saúde e Nutrição realizado em 2003-2004 nos Estados Unidos para classificar o estado nutricional dos adolescentes nas seguintes categorias: "baixo peso", "sobrepeso", "em risco de sobrepeso" e "peso normal" de acordo com os índices de massa corpórea (IMC). Apesar de os adolescentes que estavam "sobrepeso" terem 
apresentado maior ocorrência de erosão dentária enquanto os nas categorias "em risco de sobrepeso" e "baixo peso" apresentaram menor ocorrência, nenhuma associação estatisticamente significante foi encontrada (MCGUIRE et al., 2009). Existe necessidade de se ampliar o conhecimento existente sobre a possível relação entre a prevalência de erosão dentária e o estado nutricional.

\subsubsection{Variáveis comportamentais}

As variáveis comportamentais englobam ambos os fatores etiológicos extrínsecos e os intrínsecos da erosão dentária por incluírem hábitos alimentares e hábitos de regurgitação ou vômito.

Resultados de estudos prévios têm mostrado que, dentre os fatores extrínsecos, o mais constantemente associado à alta prevalência de erosão dentária em crianças é o hábito da ingestão frequente de bebidas ácidas (MILLWARD; SHAW; SMITH, 1994; O’BRIEN, 1994). Mudanças nos hábitos alimentares evidenciam um sensível aumento no consumo de bebidas e alimentos ácidos (MILLWARD; SHAW; SMITH, 1994; SHAW; SMITH, 1994). Devido à escassez de tempo em suas rotinas diárias intensas, as pessoas optam por bebidas prontas para consumir (TEIXEIRA, 2007) como sucos artificiais, refrigerantes, chás gelados, isotônicos esportivos e energéticos que, na sua grande maioria, são ácidos e erosivos. 
O consumo de sucos de frutas e de outras bebidas ácidas tem aumentado nos últimos 20 anos na América do Norte (MILLWARD; SHAW; SMITH, 1994) e aumentou em 7 vezes de 1950 para 1990 no Reino Unido (SHAW; SMITH, 1994). No Brasil, o mercado de refrigerantes dobrou de 2000-2005 (JORNAL DO BRASIL, 2005), já é o $3^{\circ}$ maior do mundo depois dos EUA e do México (ABIR, 2009), movimentando cerca de 14 bilhões de litros por ano (ABIR, 2009). O consumo per capita de refrigerantes na região Sudeste do Brasil é de 81 litros por ano (ABIR, 2009). Nesta mesma região do país, em São Paulo, dados recentes do Ministério da Saúde evidenciam um alto consumo de refrigerante entre bebês a partir do sexto mês de vida (MINISTÉRIO DA SAÚDE, 2009).

A grande maioria dos estudos epidemiológicos de erosão dentária que se propôs a investigar a associação desta com o consumo de bebidas ácidas encontrou que a prevalência aumenta com o aumento na frequência de ingestão (AL-MAJED; MAGUIRE; MURRAY, 2002; AL-MALIK; HOLT; BEDI, 2001; HARDING et al., 2003; HINDS; GREGORY, 1995; LUO et al., 2005; MILLWARD et al., 1994). De acordo com Nunn et al. (2003), no National Diet and Nutrition Survey de 1992-93, a prevalência de erosão dentária em incisivos superiores foi significantemente maior em crianças de $3 \frac{1}{2}$ a $4 \frac{1}{2}$ de idade que consumiam refrigerantes quase todos os dias (19\% de prevalência em superfícies vestibulares e $43 \%$ de prevalência nas superfícies palatinas) do que naquelas cujo consumo era menos frequente $(12 \%$ nas superfícies vestibulares e $28 \%$ nas superfícies palatinas).

No que se refere às variáveis comportamentais relacionadas ao fator etiológico intrínseco da erosão dentária, a causa mais frequente do contato excessivo entre o ácido gástrico e as superfícies dentais em crianças de pouca idade é o refluxo gastroesofágico. Este refluxo ocorre devido à passagem 
involuntária do conteúdo gástrico para o esôfago inferior que se manifesta através da regurgitação ou do vômito (SHERMAN et al., 2009). A definição de regurgitação, por sua vez, é de passagem do conteúdo do refluxo para a faringe e a cavidade oral, podendo ser ejetado desta, o que ocorre quando há o relaxamento do esfíncter esofágico inferior (SHERMAN et al., 2009).

Ambos o refluxo e a regurgitação são comuns e considerados fisiológicos em recém-nascidos e bebês com até um ano de idade (DAHSHAN et al., 2002; LUSSI; JAEGGI, 2006; SHERMAN et al., 2009). Porém, quando persistem após os 2 anos de idade e causam desconforto ou complicações, constituem um quadro clínico conhecido como doença do refluxo gastroesofágico (DRGE) (SHERMAN et al., 2009). Ocasionalmente, pode ocorrer um tipo de refluxo conhecido como "assintomático" ou "silencioso", em que o paciente não apresenta nenhum dos sinais da doença, mas pode já apresentar um quadro de desgaste por erosão dentária (ALMALIK; HOLT; BEDI, 2001). Nestes casos, o cirurgião-dentista pode ser o primeiro profissional da área da saúde a suspeitar do quadro de DRGE, devendo estar atento e encaminhar o paciente ao tratamento médico.

Dentre os estudos que investigaram a prevalência de erosão dentária especificamente em populações de crianças com DRGE (AINE; BAER; MÄKI, 1993; DAHSHAN et al., 2002; ERSIN et al., 2006; LINNETT et al., 2002; O'SULLIVAN et al., 1998), somente dois incluíram um grupo controle (ERSIN et al., 2006; LINNETT et al., 2002). Uma maior prevalência de erosão dentária foi relatada entre crianças com DRGE do que no grupo controle, onde estas foram respectivamente $76 \%$ e $10 \%$ (ERSIN et al., 2006) e 14\% e 10\% (LINNETT et al., 2002). Dahshan et al. (2002) e Aine, Baer e Mäki (1993) também observaram uma alta prevalência de erosão dentária entre crianças diagnosticadas com DRGE, respectivamente $83,3 \%$ e $87 \%$. 
Já o estudo de O'Sullivan et al. (1998) mostra que a prevalência de erosão entre crianças com DRGE foi baixa (17\%) quando comparada à observada no levantamento nacional do Reino Unido (O'BRIEN, 1994).

Recentemente, os resultados de uma revisão sistemática comprovaram que há uma forte associação entre a ocorrência de erosão dentária e a DRGE (PACE et al., 2008).

Foram encontrados seis estudos sobre a prevalência de erosão dentária em dentes decíduos na população geral que avaliaram a associação com o refluxo gastroesofágico (HARDING et al., 2003; LUO et al., 2005; MILLWARD et al., 1994; NUNN et al., 2003; RIOS et al., 2007; WIEGAND et al., 2006). Dentre estes, somente um estudo verificou uma prevalência significantemente maior de erosão dentária entre crianças de 4 a 6 anos de idade com sintomas relatados de refluxo gastroesofágico (RGR) (NUNN et al., 2003).

Adicionalmente, a ausência de um teste de diagnóstico único que comprove a presença de DRGE na infância dificulta a comparação de resultados obtidos em diferentes estudos (SHERMAN et al., 2009). Cabe salientar que a ocorrência de ambos a DRGE e a erosão dentária pode ser modificada pelo consumo de alimentos e bebidas ácidas e que, apesar de existir uma associação estabelecida entre as duas doenças, não existe evidência científica no momento para se estabelecer uma relação de causalidade (PACE et al., 2008; TOLIA; VANDENPLAST; 2009). 
2.3.5 Variáveis relacionadas às características da criança

A maioria dos autores concorda que há um aumento na prevalência de erosão dentária de acordo com o aumento da idade (CHADWICK; PENDRY, 2003; HINDS; GREGORY, 1995; NUNN et al., 2003; O'BRIEN, 1994; WIEGAND et al., 2006). Com relação à variável sexo, nenhum dos estudos realizados em crianças de 36 a 59 meses de idade observou diferenças estatisticamente significativas. Entre os estudos realizados em crianças mais velhas com dentes decíduos, um deles encontrou uma maior prevalência entre meninos do que entre meninas de 6 a 12 anos de idade (MANGUEIRA; SAMPAIO; OLIVEIRA, 2009). Possíveis explicações para esta diferença têm sido postuladas acerca do consumo mais frequente de bebidas ácidas e também com relação à maior tonicidade dos músculos mastigatórios em meninos. Entretanto, na maioria dos casos, não há diferenças estatisticamente significativas relatadas entre os sexos para a prevalência de erosão dentária nesta faixa etária (DESHPANDE; HUGAR, 2004; HARDING et al., 2003; JONES; NUNN, 1995; KAZOULLIS et al., 2007; LUO et al., 2005; MILLWARD et al., 1994; NUNN et al., 2003; WIEGAND et al., 2006).

Outros dois fatores que, no presente estudo, foram considerados como características da criança e que podem influenciar na ocorrência de erosão dentária são a presença de placa bacteriana e a de lesões de cárie.

Alguns autores têm sugerido que a presença de placa bacteriana pode servir como uma barreira mecânica que protege a superfície dentária contra o desenvolvimento de lesões erosivas (CHEUNG et al., 2005; JOHANSSON; 
LINGSTRÖM; BIRKHED, 2002). Porém, essa associação ainda não foi confirmada em estudos epidemiológicos.

Com relação à associação entre a prevalência de erosão dentária e de cárie dentária na literatura, dois estudos identificaram uma maior prevalência de erosão dentária em crianças com lesões de cárie (DUGMORE; ROCK, 2004a; KAZOULLIS et al., 2007. O fato de muitos dos elementos da dieta cariogênica serem também erosivos pode explicar este achado. Por outro lado, quatro trabalhos encontraram uma prevalência de erosão dentária semelhante entre crianças com e sem lesões de cárie (AL-MALIK; HOLT; BEDI, 2001; KÜNZEL; CRUZ; FISCHER, 2000; TRUIN et al., 2005; VAN RIJKOM et al., 2002). É importante salientar que no estudo de AlMalik, Holt e Bedi (2001), quando foram excluídos os casos de cárie rampante da análise, a prevalência de cárie passou a ser um fator associado à ocorrência de erosão dentária. 


\section{PROPOSIÇÃO}

Os objetivos deste trabalho foram avaliar a prevalência, a distribuição e o grau de acometimento das lesões de erosão dentária em crianças de 36 a 59 meses idade no município de Diadema, São Paulo.

Em posse desses dados, este trabalho também teve o objetivo de investigar os indicadores de risco socioeconômicos, ambientais, nutricionais, comportamentais e de características da criança associados à prevalência de erosão dentária. 


\section{POPULAÇÃO, MATERIAL E MÉTODOS}

O presente estudo fez parte de um projeto maior intitulado "Levantamento epidemiológico sobre as condições de saúde bucal de crianças de 12 a 59 meses de idade no município de Diadema - São Paulo" que foi submetido e aprovado pelo Comitê de Ética em Pesquisa da Faculdade de Odontologia da Universidade de São Paulo, de acordo com o protocolo 19/2008 (Anexo D). O levantamento sobre a erosão dentária foi realizado em crianças de 36 a 59 meses (3 e 4 anos) de idade, de ambos os sexos, no município de Diadema, São Paulo, no dia da primeira etapa da Campanha Nacional de Multivacinação Infantil em 14 de junho de 2008 com autorização da Secretaria Municipal de Saúde (Anexo E).

\subsection{Características sociodemográficas da população}

Localizado na região sudeste da Grande São Paulo, o município de Diadema faz parte do pólo industrial do ABCD paulista. Sua extensão territorial é de 30,65 $\mathrm{Km}^{2}$, está dividido em 17 micro-regiões administrativas e possui grau de urbanização de $100 \%$. Em 2009, sua população estimada era de 396.955 habitantes, gerando uma densidade demográfica de 12.951 habitantes/Km² (SEADE, 2009). Dentro desta população, o número estimado de crianças de 0-4 anos de idade era de 34.647 em 2008 (MINISTÉRIO DA SAÚDE, 2008). 
Com relação aos indicadores sociais de condições de vida, Diadema apresenta um Índice de Desenvolvimento Humano de 0,790 (SEADE, 2009), sendo considerado um município de médio desenvolvimento humano pela UNICEF (Fundo das Nações Unidas para a Infância) (UNICEF, 2006). O IDH é um índice que tem como base três aspectos: a educação, a longevidade e a renda. No caso da população infantil, o Índice de Desenvolvimento Humano Infantil (IDI) da UNICEF mensura a qualidade de vida de crianças de 0-6 anos de idade, numa escala de 0 a 1, por meio da análise do grau de escolaridade dos pais, taxas de vacinação, mortalidade infantil, número de crianças matriculadas em creches e pré-escolas e percentual de gestantes que realizaram exames pré-natais. Os últimos dados disponíveis mostram que em 2006 o IDI em Diadema foi de 0,825 , ocupando a 192ª posição entre municípios paulistas e a 365ํㅗㄹ posição entre os municípios brasileiros (UNICEF, 2006). Além disso, a Taxa de Mortalidade Infantil de Diadema em 2007 foi de 14,78 óbitos a cada mil nascidos vivos.

Especificamente sobre o aspecto socioeconômico do município de Diadema, uma análise realizada em 2000 pela Secretaria de Economia e Planejamento indicou que os responsáveis pelos domicílios recebiam uma média de $R \$ 618,00$, sendo que $51,8 \%$ ganhavam no máximo três salários mínimos (SEADE, 2009). O PIB (Produto Interno Bruto) per capita de Diadema em 2006 foi de $\mathrm{R} \$ 19.596$ (IBGE, 2009) e a renda per capita em 2000 era de 1,94 salários mínimos (SEADE, 2009).

Com relação à educação, dados do Censo 2000 apontaram uma taxa de analfabetismo de 6,8\% na população de 15 ou mais anos de idade. Dentro da população de 18 a 24 anos, somente 35,29\% possuíam ensino médio completo (SEADE, 2009). 
No que diz respeito ao saneamento básico, no ano de $2000,99,6 \%$ da população de Diadema possuía coleta de lixo, 92,22\% possuía esgoto sanitário e 99,08\% recebia abastecimento de água (SEADE, 2009). Desde 1986, 98,7\% da população de Diadema tem acesso à água tratada e fluoretada $(0,77 \mathrm{ppm} F$ ) (PREFEITURA DE DIADEMA, 2009).

\subsection{Casuística}

Do ponto de vista ético e operacional, a avaliação da população em sua totalidade torna-se impraticável (PINTO, 2000). Portanto, para obter resultados cientificamente confiáveis, foi avaliada uma amostra das crianças entre 36 e 59 meses (3 e 4 anos) de idade, de ambos os sexos, residentes no município de Diadema.

O tamanho mínimo da amostra representativa foi estimado utilizando-se a fórmula descrita por Kirkwood (1988). O cálculo dessa fórmula leva em consideração o erro padrão e o intervalo de confiança assumido pelo pesquisador, bem como a prevalência prévia de erosão da população estudada (Figura 4.1). Inicialmente, estipulou-se o erro padrão como sendo menor do que 1,7\% e um intervalo de confiança de $95 \%$. Devido à inexistência de dados sobre a prevalência de erosão dentária em populações brasileiras de pré-escolares, foi adotada a prevalência de $50 \%$ para o cálculo do tamanho amostral. 


Amostra populacional $=\frac{\pi(1-\pi)}{e^{2}}$
$\pi=\%$ da população com prevalência de lesões erosivas $(0,50)$
$e=$ erro padrão $=0,017$

Figura 4.1- Fórmula para cálculo do tamanho amostral

Por meio deste cálculo, inferiu-se que a amostra populacional mínima para o estudo seria de 865 crianças. Com o intuito de prevenir perdas eventuais e distribuir o número de crianças examinadas uniformemente entre os 13 pontos de coleta de amostra, estipulou-se uma amostra de 962 crianças a serem avaliadas, sendo 74 crianças em cada um das 13 UBSs. Segundo a OMS (Organização Mundial da Saúde), ao se considerar que sempre haverá alguma variação entre os examinadores (CDs), apesar dos exercícios de treinamento e calibração, é aconselhável que estes examinem percentuais semelhantes de cada grupo da amostra (WHO, 1997). Portanto, cada examinador coletou dados de 37 crianças de cada uma das duas faixas etárias incluídas no estudo.

Com a finalidade de se universalizar a amostra e não incorrer em distorções de representatividade, os dados foram coletados durante a Campanha de Multivacinação, na primeira etapa ocorrida no dia 14 de junho de 2008.

Um dos critérios de inclusão para o levantamento epidemiológico de erosão dentária foi que a criança possuísse a dentição decídua completa, crianças com menos de 36 meses não foram examinadas. 


\subsection{Treinamento e calibração dos membros das equipes}

Os exercícios de treinamento e calibração têm como objetivo eliminar ou reduzir discordâncias, de modo a selecionar os examinadores mais aptos a utilizarem de maneira confiável os critérios estabelecidos para o estudo em questão (PINTO, 2000).

Em cada uma das 13 UBS havia uma equipe composta por um cirurgiãodentista examinador geral, um cirurgião-dentista examinador exclusivo de erosão dentária, dois auxiliares de saúde bucal (ASB) (um organizador de fluxo e um anotador), um auxiliar de enfermagem (AE) e um agente comunitário de saúde (ACS).

Os cirurgiões-dentistas examinadores gerais avaliaram a presença de cárie dentária, lesão dentária traumática e maloclusão e foram selecionados entre os profissionais que trabalhavam na Secretaria Municipal de Saúde de Diadema. Os examinadores gerais foram calibrados utilizando o índice ceo-d para o propósito do levantamento sobre cárie dentária, um dos indicadores de risco possivelmente associado à presença de erosão dentária.

Os examinadores de erosão dentária foram cirurgiões-dentistas especialistas ou alunos de pós-graduação em Odontopediatria. Estes foram treinados e calibrados para o diagnóstico de erosão dentária utilizando o índice de O'Brien (1994) modificado.

A seleção dos examinadores gerais e de erosão dentária foi feita de acordo com os resultados de concordância obtidos após o exercício de calibração para diagnóstico dos respectivos problemas de saúde bucal. 
O treinamento e a calibração dos examinadores foram realizados em duas etapas com um intervalo de uma semana entre cada fase e em grupos separados para a erosão dentária e para a cárie dentária. Foram utilizados slides de fotos clínicas e também molares e incisivos decíduos concedidos pelo Banco de Dentes Humanos da Faculdade de Odontologia da USP, estando este segundo método de calibração previamente descrito na literatura (ARDENGHI; BÖNECKER; TOLLARA, 2003; CLEATON-JONES et al., 1989;). Os dentes utilizados nas calibrações, tanto para o diagnóstico de erosão dentária quanto para o de cárie dentária, foram selecionados de modo que todos os graus de acometimento das respectivas lesões estavam representados.

Cada sessão de treinamento teve duração de quatro horas, sendo que a última sessão foi realizada uma semana antes do dia do exame clínico e coleta de dados. Os resultados dos exercícios de calibração foram descritos utilizando os índices de concordância de Cohen's Kappa, que representa as concordâncias esperadas descontando-se as que ocorrem por acaso. Para o cálculo deste índice, foram utilizados os dados do diagnóstico de cada examinador para as diferentes superfícies avaliadas. Os valores médios de Kappa intra e interexaminadores estão descritos na tabela 4.1 para erosão dentária e na tabela 4.2 para cárie dentária.

Tabela 4.1 - Valores médios de Kappa intra e interexaminadores para o diagnóstico de erosão dentária

\begin{tabular}{l|c|c}
\hline & Kappa intra-examinador & Kappa Interexaminadores \\
\hline Profundidade da lesão & 0,74 & 0,81 \\
\hline Área da lesão & 0,62 & 0,69 \\
\hline
\end{tabular}


Tabela 4.2 - Valores médios de Kappa intra e interexaminadores para o diagnóstico de cárie dentária

\begin{tabular}{l|c|c}
\hline & Kappa intra-examinador & Kappa Interexaminadores \\
\hline ceo-d & 0,83 & 0,75 \\
\hline
\end{tabular}

Os ASBs receberam duas sessões de treinamento com uma semana de intervalo entre elas, onde foram instruídos e treinados para o preenchimento da ficha clínica e foram orientados sobre a dinâmica de exames e fluxo de participantes que ocorreria no dia da coleta. Os ACSs também estavam presentes nas reuniões para serem orientados sobre o fluxo de participantes. O último treinamento ocorreu uma semana antes da coleta.

Os AEs foram treinados e calibrados para a mensuração de peso e altura de acordo com o padrão de referência da OMS (WHO CHILD GROWTH STANDARDS, 2006), utilizando-se aula em multimídia, bonecas, balanças e estadiômetros.

\subsection{Coleta de dados}

O fluxo das crianças examinadas e as funções dos membros da equipe no dia do exame clínico e coleta de dados estão ilustrados na figura 4.2. 


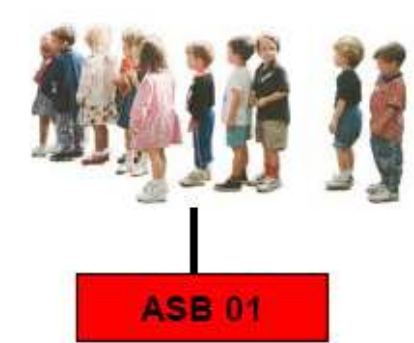

- convidar cada $5^{a}$ criança da fila a participar da pesquisa

- explicar pesquisa e obter assinatura do responsável no Termo de Consentimento Livre e Esclarecido (no verso da ficha) e Preencher Ficha de Identificação e Questionário Socioeconômico

\section{AE}

- medidas de peso \& altura

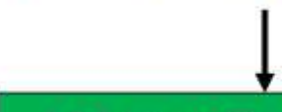

ACS (na porta do consultório)
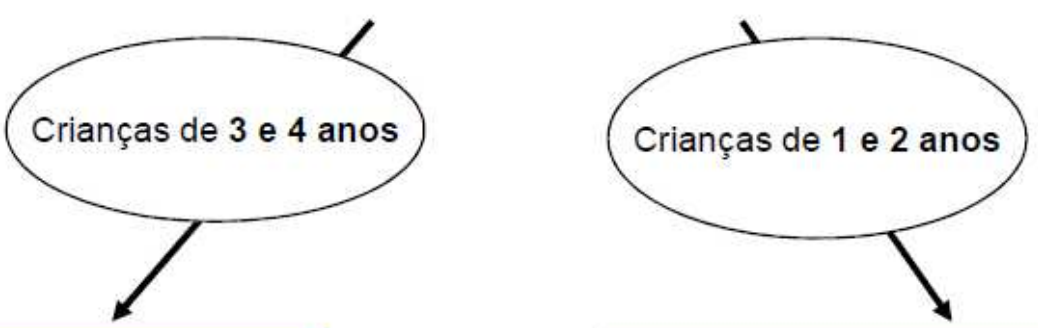

\section{Examinador de Erosäo}

Examinador Geral

\section{ASB 02}

\section{- ANOTAR PLACA BACTERIANA}

- examinar erosão dental $\left(1^{\circ}\right)$

- examinar cárie, trauma e maloclusão

- preencher questionário de erosão $\left(2^{\circ}\right)$

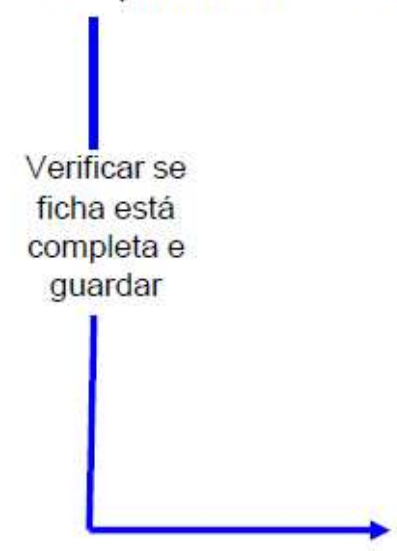

\section{VACINA}

- anotar exames

Verificar se ficha está completa e guardar

Figura 4.2 - Fluxograma do dia da coleta 


\subsubsection{Seleção das crianças que compuseram a amostra}

Um dos ASBs (ABS 01 na Figura 4.2) tinha a função de convidar a criança e seu responsável que ocupavam a quinta posição na fila de vacinação para participarem do estudo. Nos casos de não permissão ou não concordância para realização do exame, a criança seguinte na fila era convidada e assim sucessivamente. Com o intuito de não introduzir viés de seleção, foi tomado o cuidado de não examinar irmãos ou crianças que residiam no mesmo domicílio.

Caso o responsável aceitasse o convite, o Termo de Consentimento Livre e Esclarecido (Apêndice A) era preenchido e assinado. Neste momento, a ficha de identificação e o questionário socioeconômico foram também preenchidos. A criança foi então conduzida à sala onde o $\mathrm{AE}$ (Figura 4.2) aferiu as medidas antropométricas. Posteriormente, o ACS (Figura 4.2) ficou responsável por orientar o fluxo de crianças de 36 a 59 meses (3 e 4 anos) de idade diretamente para o examinador de erosão dentária no consultório odontológico e crianças de 1 e 2 anos ao examinador geral

Todos os examinadores de erosão dentária foram instruídos para realizar primeiramente o exame clínico e, somente depois, preencher o questionário sobre erosão dentária. Foram também orientados para anotar a presença ou ausência de placa bacteriana visível na superfície vestibular dos incisivos superiores antes de realizar a limpeza destes com gaze para o exame clínico. Após o exame de erosão dentária e o preenchimento do questionário de erosão, a criança era encaminhada para o examinador geral para verificar a presença de cárie dentária, lesão dentária traumática e maloclusão. Após completar o número de crianças de 36 a 59 meses de idade necessários para a amostra do estudo sobre cárie dentária, os 
participantes do estudo sobre erosão dentária foram encaminhados direto do examinador de erosão para a vacina.

O ABS 02 (Figura 4.2) era responsável por anotar os dados do exame clínico do examinador geral na ficha clínica.

Todos os dados coletados foram anotados em uma única ficha clínica desenvolvida especialmente para este estudo (Apêndice B).

A coleta dos dados e o exame clínico foram realizados antes de a criança ser vacinada, a fim de se evitar a manipulação da cavidade bucal após o recebimento da vacina em gotas.

\subsubsection{Exame Clínico}

Os exames clínicos foram conduzidos em cadeiras odontológicas dos consultórios das UBSs, sob luz artificial do refletor acoplado ao equipo odontológico e com o auxílio de um espelho bucal plano $\mathrm{n}^{\circ} 5$. A cadeira foi colocada em posição horizontal e a criança posicionada em decúbito dorsal. Inicialmente, foi verificada a presença de placa bacteriana na superfície vestibular dos incisivos superiores através do método visual, sem utilização de evidenciador (ALALUUSUA; MALMIVIRTA, 1994).

A seguir, foi realizada a limpeza das superfícies dentárias a serem avaliadas com uma gaze embebida em água. Os elementos dentários foram então isolados com roletes de algodão e as superfícies foram secas com o auxílio da seringa de ar 
para melhor visualização e avaliação de diagnóstico. O dente foi considerado erupcionado quando qualquer parte dele estivesse visível (supragengival).

\subsubsection{Critérios para diagnóstico de erosão dentária}

A lesão característica da erosão é lisa, com contornos arredondados, sem pigmentação e acomete principalmente as superfícies palatinas dos dentes anteriores superiores (Figura 4.3) e as oclusais dos dentes posteriores (DEERY et al., 2000; JÄRVINEN; RYTÖMAA; MEURMAN, 1992; WIEGAND et al., 2006).

Na maioria dos casos, as lesões erosivas iniciais são maiores em área do que em profundidade e a face dental acometida apresenta-se lisa devido à descaracterização do esmalte, que perde as periquimatas. A lesão erosiva também apresenta um aspecto excessivamente brilhante e é circundada por um halo translúcido bastante nítido, correspondente à região da junção amelodentinária (Figuras 4.4 e 4.5) (CORRÊA; BEGOSSO; NASSIF, 2002; DESHPANDE; HUGAR, 2004; ECCLES, 1979; GANDARA; TRUELOVE, 1999; KÜNZEL; CRUZ; FISCHER, 2000). Esta perda da caracterização do esmalte pode ser encontrada mesmo em crianças de pouca idade (GANDARA; TRUELOVE, 1999; JAEGGI; LUSSI, 2006). 


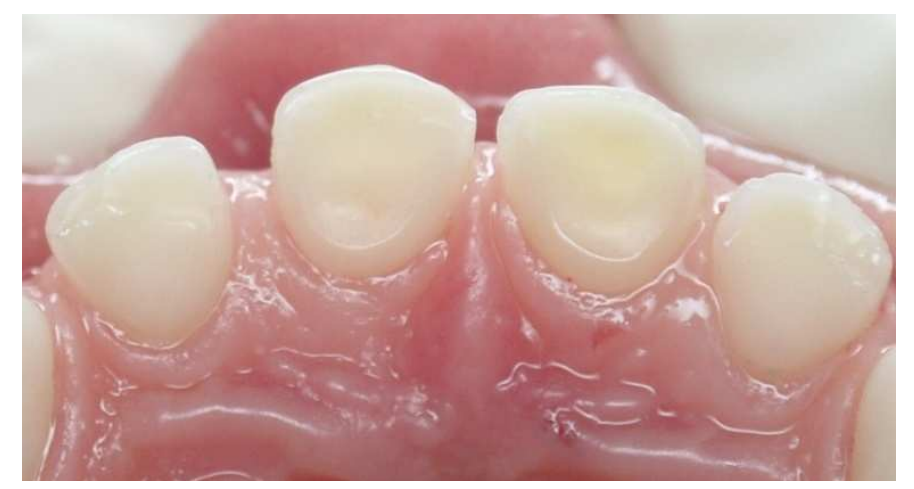

Figura 4.3 - Lesão inicial. Brilho excessivo por descaracterização do esmalte

Nas superfícies oclusais, as lesões iniciais podem se apresentar como pequenos pontos socavados, conhecidos como cuppings e as fissuras e sulcos vão deixando de ser evidentes (Figura 4.4) (CORRÊA; BEGOSSO; NASSIF, 2002; DESHPANDE; HUGAR, 2004; GANSS; KLIMEK; GIESE, 2001). Se o fator etiológico não for removido ou controlado, na medida em que os "cuppings" progridem, a lesão erosiva atinge a dentina (DEERY et al., 2000; GANDARA; TRUELOVE, 1999; GANSS; KLIMEK; GIESE, 2001; JÄRVINEN; RYTÖMAA; MEURMAN, 1992). Além disso, a hiperestesia dentinária, a perda dos contornos dentários e as restaurações em amálgama salientes em "ilhas" (Figura 4.4) também são sinais relatados na literatura, que podem estar presentes (CORRÊA; BEGOSSO; NASSIF, 2002; DESHPANDE; HUGAR, 2004; GANDARA; TRUELOVE, 1999). Muitas vezes a região mais cervical da superfície dental erodida fica preservada devido à presença protetora do fluido crevicular (DESHPANDE; HUGAR, 2004). 


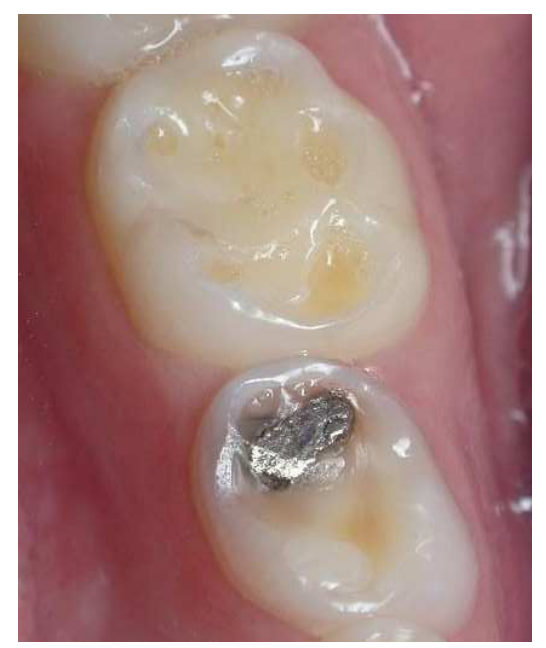

Figura 4.4 - Cuppings em dentina no segundo molar inferior esquerdo e ilha de amálgama no primeiro molar inferior esquerdo

Em casos extremos, é possível observar desgaste com proximidade pulpar (Figura 4.5), incapacidade de estabelecer contato oclusal e, até mesmo, perda de dimensão vertical (CORRÊA; BEGOSSO; NASSIF, 2002; DESHPANDE; HUGAR, 2004; LUO et al., 2005; MAHONEY; KILPATRICK, 2003).

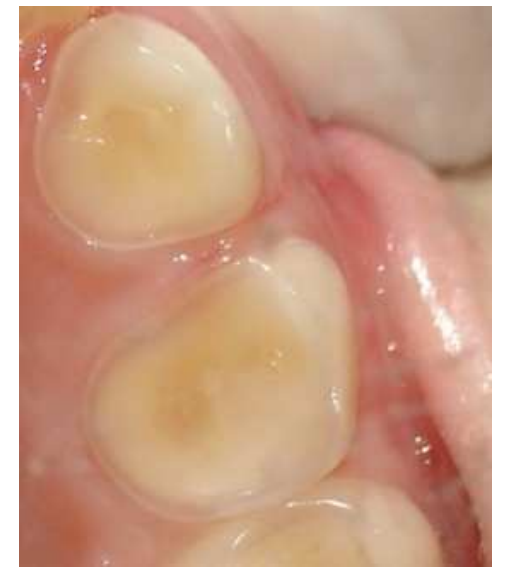

Figura 4.5 - Lesões com proximidade pulpar. Halo translúcido nítido

O índice utilizado para avaliação de lesões erosivas na presente pesquisa foi baseado em O'Brien (1994) e modificado (Tabela 4.3). 
A modificação introduzida ao índice de O'Brien (1994) foi baseada em estudo prévio realizado em São Paulo com uma amostra de 50 crianças (MURAKAMI et al., 2006), utilizando este mesmo índice (Anexo B). Observou-se que nenhuma lesão erosiva obteve o código 3 de profundidade, ou seja, nenhuma lesão apresentava sangramento ou exposição pulpar visível.

Provavelmente, este achado deve-se ao fato de a erosão dentária ser um processo crônico (LUSSI; JAEGGI; ZERO, 2004), possibilitando a formação de dentina reparacional que protege contra a exposição pulpar. Porém, foi observado um desgaste atingindo proximidade pulpar, com uma fina camada de dentina remanescente, já possibilitando a visualização, por translucidez, da coloração vermelha da polpa ou do escurecimento da dentina reparacional. Portanto, considerou-se recomendável a alteração da descrição do critério clínico de código 3 de O'Brien (1994) para a profundidade da lesão, conforme ilustrado na tabela 4.3.

Tabela 4.3 - Índice de O'Brien (1994) Modificado

\begin{tabular}{l|l}
\hline \multicolumn{1}{l}{ PROFUNDIDADE } \\
\hline 0 & Normal (hígido) \\
\hline 1 & Somente em esmalte - perda da caracterização da superfície \\
\hline 2 & Em esmalte e dentina - perda de esmalte, expondo a dentina \\
\hline 3 & $\begin{array}{l}\text { Em esmalte e dentina com proximidade pulpar - observa-se vermelhidão da polpa ou o } \\
\text { escurecimento da dentina reparacional por translucidez do tecido remanescente }\end{array}$ \\
\hline 9 & Avaliação não pôde ser feita \\
\hline & \\
\hline 0 & ÁREA \\
\hline 1 & Acometendo menos de $1 / 3$ da superfície \\
\hline 2 & Acometendo de 1/3 a $2 / 3$ da superfície \\
\hline 3 & Acometendo mais de $2 / 3$ da superfície \\
\hline 9 & Avaliação não pôde ser feita \\
\hline
\end{tabular}


Segundo este índice, a superfície examinada recebeu escore 9 de profundidade quando não foi possível realizar a avaliação devido à ausência do elemento dental, à presença de uma coroa total ou de uma lesão cariosa extensa comprometendo toda a superfície. Caso contrário, a profundidade da lesão foi classificada observando-se o tecido dental adjacente às restaurações e lesões cariosas menores. O escore 9 de área, por outro lado, foi considerado sempre que a superfície avaliada apresentasse selantes, restaurações ou lesões cariosas de qualquer extensão, por menor que fossem, que impossibilitam a avaliação da quantidade da área acometida.

Como diversos autores já observaram que as superfícies mais comumente acometidas por erosão dentária são as palatinas dos incisivos superiores (DUGMORE; ROCK, 2004b; JÄRVINEN; RYTÖMAA; MEURMAN, 1992) e as oclusais dos $1^{0}$ molares inferiores (GANSS; KLIMEK; GIESE, 2001; MATHEW; CASAMASSIMO; HAYES, 2002), estas foram as superfícies índices avaliadas no presente estudo.

Para a determinação da área da superfície acometida, a mesma foi dividida em terços de maneira padronizada como ilustrado na figura 4.6
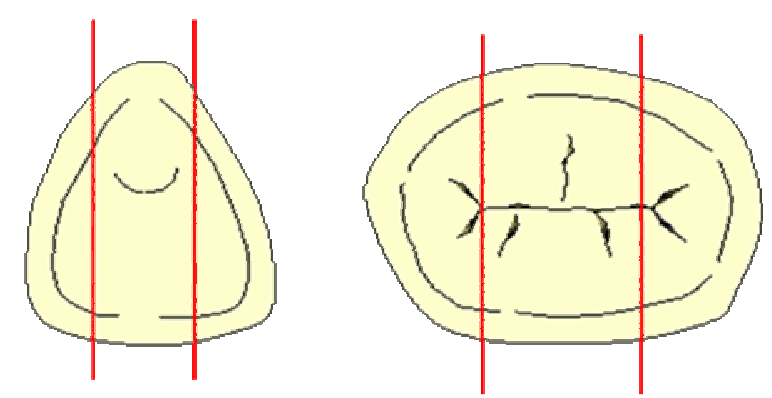

Figura 4.6 - Padronização da divisão das superfícies em terços 
Cada superfície recebeu um código para a profundidade e outro para a área acometida pela lesão, conforme o Índice de O'Brien (1994) modificado (Tabela 4.3) e estes escores foram anotados na ficha clínica em quadrados distintos na palatina dos incisivos superiores (Figura 4.7a) e na oclusal dos molares inferiores (Figura 4.7b). O escore para profundidade da lesão erosiva foi anotado no quadrado da esquerda. O quadrado da direita recebeu o escore indicando a área acometida pela lesão. Em caso de dúvida, o escore de menor gravidade foi anotado (MILLWARD et al., 1994).

(a)

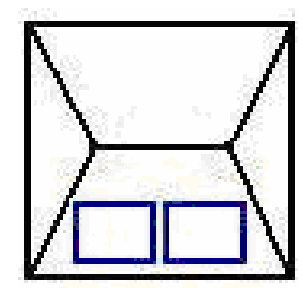

(b)

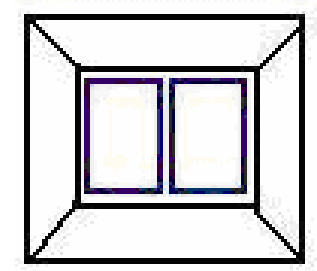

Figura 4.7 - Locais para anotação de escores de erosão dentária.

É importante salientar que, para obter dados mais confiáveis, na aplicação deste índice, a profundidade da lesão deve sempre ser avaliada antes da área porque, para a avaliação da área da lesão, deve-se considerar a área da pior profundidade. Esta metodologia foi utilizada para a classificação no presente estudo.

\subsubsection{Critérios para diagnóstico de cárie dentária}

A gravidade da experiência de cárie em dentes decíduos foi mensurada utilizando-se os índices ceo-d e ceo-s, descritos por Gruebbel (1944). Os elementos dentários e/ou superfícies presentes na cavidade bucal foram codificados como 
cariados (c), indicados para extração (e) ou obturados (o). Para descrever a prevalência de crianças afetadas pela doença cárie, utilizou-se o índice de Knutson (1944), através do qual se obtiveram dois grupos: crianças que têm ou tiveram experiência de cárie (ceo>0) e crianças que nunca tiveram experiência de cárie (ceo=0). Lesões incipientes (mancha branca) não foram consideradas para o propósito do presente estudo.

Os parâmetros adotados para o diagnóstico de lesões cariosas foram baseados nos critérios recomendados pela Organização Mundial de Saúde (1999) e adaptados por Pinto (2000). O dente foi considerado com extração indicada (e) quando apresentava apenas raízes ou coroa destruída não permitindo reconstrução com restaurações convencionais. A superfície foi considerada cariada (c) quando existia: cavidade evidente; lesão em sulco, fissura ou superfície lisa com tecido amolecido na base, descoloração de esmalte ou de parede; restauração definitiva e uma ou mais áreas com lesão de cárie concomitantemente; restauração temporária. A superfície foi considerada obturada (o) quando uma ou mais restaurações definitivas estavam presentes e inexistia lesão de cárie ou quando um dente apresentava coroa. A superfície foi considerada hígida quando não apresentava nenhuma das alterações descritas acima e estava sadia. Em caso de dúvida, a superfície era considerada hígida.

\subsubsection{Questionário para investigação de variáveis associadas}

Os indicadores de risco possivelmente associados à prevalência de erosão dentária foram investigados por meio da aplicação de um questionário elaborado 
especificamente para este estudo com base na literatura (Apêndice B). Os examinadores ou anotadores liam as questões para os responsáveis dos participantes e anotavam as respostas.

\subsubsection{Variáveis socioeconômicas}

As variáveis investigadas no questionário socioeconômico compõem o índice de Jarman (JARMAN, 1983) e foram previamente utilizadas em estudos epidemiológicos sobre cárie dentária e lesões dentárias traumáticas no município de Diadema (ARDENGHI; BÖNECKER; TOLLARA, 2003; BÖNECKER, 1999; BÖNECKER, 2005; BONINI, 2008; OLIVEIRA, 2006). O nível socioeconômico foi avaliado de acordo com as seguintes variáveis: estrutura familiar, nível de escolaridade dos pais e renda familiar. A renda familiar foi calculada somando-se os salários mensais dos membros ativos da família e dividindo pelo salário mínimo (SM) atual ( $1 \mathrm{SM}=$ quatrocentos e quinze reais). 


\subsubsection{Variáveis ambientais}

Os aspectos sociais ambientais foram investigados considerando a aglomeração domiciliar, o tipo de moradia e o número de filhos, que também compõem o índice de Jarman

\subsubsection{Medidas antropométricas e avaliação do estado nutricional}

Balanças eletrônicas com capacidade de $150 \mathrm{Kg}$ e precisão de $50 \mathrm{~g}$ foram colocadas em solos planos para evitar oscilações nas medidas. As crianças foram pesadas vestindo apenas roupas leves e descalças, permanecendo eretas, no centro da balança, com os braços esticados ao longo do corpo e sem se movimentar (WHO, 1995). Para medir a estatura, as crianças foram posicionadas de pé, com os braços esticados ao longo do corpo, pés unidos e sem se movimentar (WHO, 1995), utilizando um estadiômetro com extensão de 2 metros, dividido em centímetros e subdividido em milímetros, acoplado à balança eletrônica.

O padrão da OMS (THE WHO CHILD GROWTH STANDARDS, 2006) foi utilizado na análise dos dados antropométricos da população de estudo. O estado nutricional das crianças foi avaliado de acordo com os índices peso/idade, peso/altura, altura/idade e índices de massa corpórea (IMC)/idade utilizando-se escores-Z. Quatro variáveis são necessárias para o cálculo do escore-Z: sexo, peso em quilos, idade em meses e altura em centímetros. Tais dados foram inseridos no 
Software for assessing growth and development of world's children (WHO, 2006). Crianças com escore-Z menor do que -2 foram consideradas com déficit de peso ou estatura, crianças com escore- $Z$ entre $-2 \mathrm{e}+2$ foram consideradas normais e aquelas com escore- $Z$ maior do que +2 foram consideradas obesas.

\subsubsection{Variáveis comportamentais}

Informações sobre o consumo de bebidas ácidas e sobre os hábitos de regurgitação ou refluxo gastroesofágico frequentes foram coletadas por meio de um questionário elaborado especialmente para o presente estudo, baseado na literatura (AL-MALIK; HOLT; BEDI, 2001; GANDARA; TRUELOVE, 1999). O cirurgião-dentista examinador de erosão dentária aplicou individualmente o questionário ao responsável pela criança, após a realização do exame clínico.

4.4.3.5 Variáveis relacionadas às características da criança

Os dados referentes à idade, sexo, presença de placa bacteriana (ALALUUSA; MALMIVIRTA, 1994) visível na vestibular dos incisivos superiores e presença de cárie dentária (PINTO, 2000) foram coletados e anotados na ficha clínica (Apêndice B). 


\subsection{Organização dos dados e análise estatística}

Os dados das fichas devidamente preenchidas foram inseridos em uma planilha do programa Microsoft Excel e conferidos posteriormente pela própria pesquisadora. Para a análise estatística, os dados foram transferidos para 0 software Minitab versão 15.0 .

Inicialmente, a prevalência de erosão dentária por idade, sexo e dente acometido assim como a distribuição e a gravidade das lesões erosivas foram verificadas por meio de uma análise descritiva. A análise de regressão univariada de cada um dos fatores independentes foi realizada utilizando os testes de QuiQuadrado ou teste exato de Fisher.

Em seguida, as variáveis com significância estatística de $p \leq 0,20$ foram selecionadas para entrarem no modelo de regressão logística múltipla utilizando-se o procedimento de forward stepwise selection onde se inicia pela variável com maior significância estatística na análise univariada e as variáveis seguintes são incluídas uma por uma.

Para compor o modelo final, foi realizada a análise de regressão por blocos hierarquizados, iniciando-se pelos fatores determinantes mais distantes até os mais próximos. Eram selecionadas somente as variáveis significativas no modelo múltiplo do $1^{\circ}$ bloco e procedia-se à análise de regressão in cluindo as variáveis significativas do $2^{\circ}$ bloco, e assim sucessivamente, sempre ajustan do pelas variáveis significativas dos blocos hierarquicamente superiores. Este tipo de abordagem 
permitiu quantificar a contribuição de cada nível de ajuste, facilitando a interpretação do significado de cada associação independente.

Em todos os testes realizados, o nível de significância foi estabelecido em $5 \%(\alpha=0,05)$. 


\section{RESULTADOS}

A cobertura vacinal de 2008 para a população de Diadema na faixa etária de 1 a 4 anos de idade foi de $89,24 \%$ (25.401 crianças vacinadas) na primeira fase da campanha (MINISTÉRIO DA SAÚDE, 2008). A taxa de resposta deste estudo foi de $100 \%$, não tendo ocorrido casos de recusa a participar por parte dos sujeitos da pesquisa e de seus responsáveis.

Os valores descritivos da distribuição e da porcentagem de crianças examinadas de acordo com a faixa etária e sexo estão expressos na tabela 5.1.

Tabela 5.1- Distribuição do número e porcentagem de crianças examinadas segundo a faixa etária e sexo, Diadema - SP, 2008

\begin{tabular}{|c|c|c|c|c|c|c|}
\hline \multirow{3}{*}{ Idade (meses) } & \multicolumn{4}{|c|}{ Sexo } & \multirow{2}{*}{\multicolumn{2}{|c|}{ Total }} \\
\hline & \multicolumn{2}{|c|}{ Masculino } & \multicolumn{2}{|c|}{ Feminino } & & \\
\hline & $\mathbf{n}$ & $\%$ & $\mathbf{n}$ & $\%$ & $\mathbf{n}$ & $\%$ \\
\hline $36-47$ & 241 & 47,3 & 268 & 52,7 & 509 & 52,6 \\
\hline 48- 59 & 222 & 48,5 & 236 & 51,5 & 458 & 47,4 \\
\hline Total & 463 & 47,9 & 504 & 52,1 & 967 & 100 \\
\hline
\end{tabular}

Os valores descritivos da distribuição e da porcentagem de crianças examinadas de acordo com o sexo e presença de erosão dentária estão expressos na tabela 5.2. Nesta tabela, pode-se observar que a prevalência de erosão dentária entre as 967 crianças examinadas na população estudada foi de $51,6 \%$. 
Tabela 5.2- Distribuição do número e porcentagem de crianças quanto à presença de lesões erosivas de acordo com o sexo. Diadema - SP, 2008

\begin{tabular}{|c|c|c|c|c|c|c|}
\hline \multirow{3}{*}{ Sexo } & \multicolumn{4}{|c|}{ Erosão dentária } & & \\
\hline & \multicolumn{2}{|c|}{ Sem } & \multicolumn{2}{|c|}{ Com } & \multicolumn{2}{|c|}{ Total } \\
\hline & $\mathbf{n}$ & $\%$ & $\mathbf{n}$ & $\%$ & $\mathbf{n}$ & $\%$ \\
\hline Feminino & 245 & 48,4 & 259 & 51,5 & 504 & 100 \\
\hline Masculino & 223 & 48,1 & 240 & 51,9 & 463 & 100 \\
\hline Total & 468 & 48,4 & 499 & 51,6 & 967 & 100 \\
\hline
\end{tabular}

Como não houve diferença estatisticamente significativa entre os sexos para a prevalência $(p=0,914)$, as tabelas seguintes apresentam os dados sem considerar esta variável.

A distribuição e a porcentagem das crianças com erosão dentária de acordo com a faixa etária estão expressas na tabela 5.3. Nesta, observa-se um aumento significativo $(p=0,003)$ no número de crianças que apresentavam erosão dentária de acordo com o avanço da idade.

Tabela 5.3- Distribuição do número e porcentagem de crianças quanto à presença de lesões erosivas de acordo com faixa etária. Diadema - SP, 2008

\begin{tabular}{ccccccc}
\hline \multirow{2}{*}{$\begin{array}{c}\text { Idade } \\
\text { (meses) }\end{array}$} & \multicolumn{4}{c}{ Erosão dentária } & \multicolumn{2}{c}{ Total } \\
\cline { 2 - 5 } & \multicolumn{2}{c}{ Sem } & \multicolumn{2}{c}{ Com } & \multicolumn{2}{c}{} \\
\cline { 2 - 6 } & $\mathbf{n}$ & $\%$ & $\mathbf{n}$ & $\%$ & $\mathbf{n}$ & $\%$ \\
\hline $36 \vdash 47$ & 269 & 52,8 & 240 & 47,2 & 509 & 47,2 \\
$48 \vdash 59$ & 199 & 43,4 & 259 & 56,6 & 458 & 56,6 \\
\hline Total & 468 & 48,4 & 499 & 51,6 & 967 & 100,0 \\
\hline
\end{tabular}

*Houve diferença estatisticamente significativa, $p=0,003$. Teste Qui quadrado 
A distribuição das lesões erosivas por dente examinado está ilustrada na tabela 5.4 .

Tabela 5.4 - Distribuição da porcentagem de lesões erosivas por dente examinado. Diadema - SP, 2008

\begin{tabular}{|c|c|c|c|c|}
\hline & \multirow[b]{2}{*}{ Dente } & \multirow{2}{*}{$\begin{array}{l}\text { Total de crianças } \\
\text { examinadas }\end{array}$} & \multicolumn{2}{|c|}{ Com Erosão Dentária } \\
\hline & & & $\mathbf{N}$ & $\%$ \\
\hline \multirow{4}{*}{ 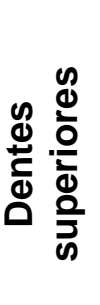 } & 52 & 967 & 344 & 35,6 \\
\hline & 51 & 967 & 366 & 37,8 \\
\hline & 61 & 967 & 356 & 36,8 \\
\hline & 62 & 967 & 335 & 36,7 \\
\hline \multirow{4}{*}{ 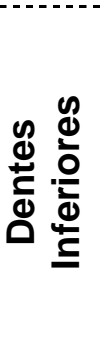 } & 75 & 967 & 196 & 20,3 \\
\hline & 74 & 967 & 211 & 21,8 \\
\hline & 84 & 967 & 203 & 21,0 \\
\hline & 85 & 967 & 203 & 21,0 \\
\hline
\end{tabular}

Nesta tabela, a porcentagem indica quantos elementos apresentaram erosão dentária por tipo de dente. As lesões erosivas foram mais frequentes em incisivos superiores do que em molares inferiores (Tabela 5.4). O dente 51 apresentou a maior frequência $(37,8 \%)$ e o dente 75 a menor (20,3\%). Observa-se também que houve uma tendência de bilateralidade e simetria no padrão de acometimento por lesões erosivas entre a arcada direita e a esquerda.

O gráfico 5.1 ilustra a distribuição da porcentagem de dentes acometidos, de acordo com o grau de acometimento em profundidade de lesões erosivas. 


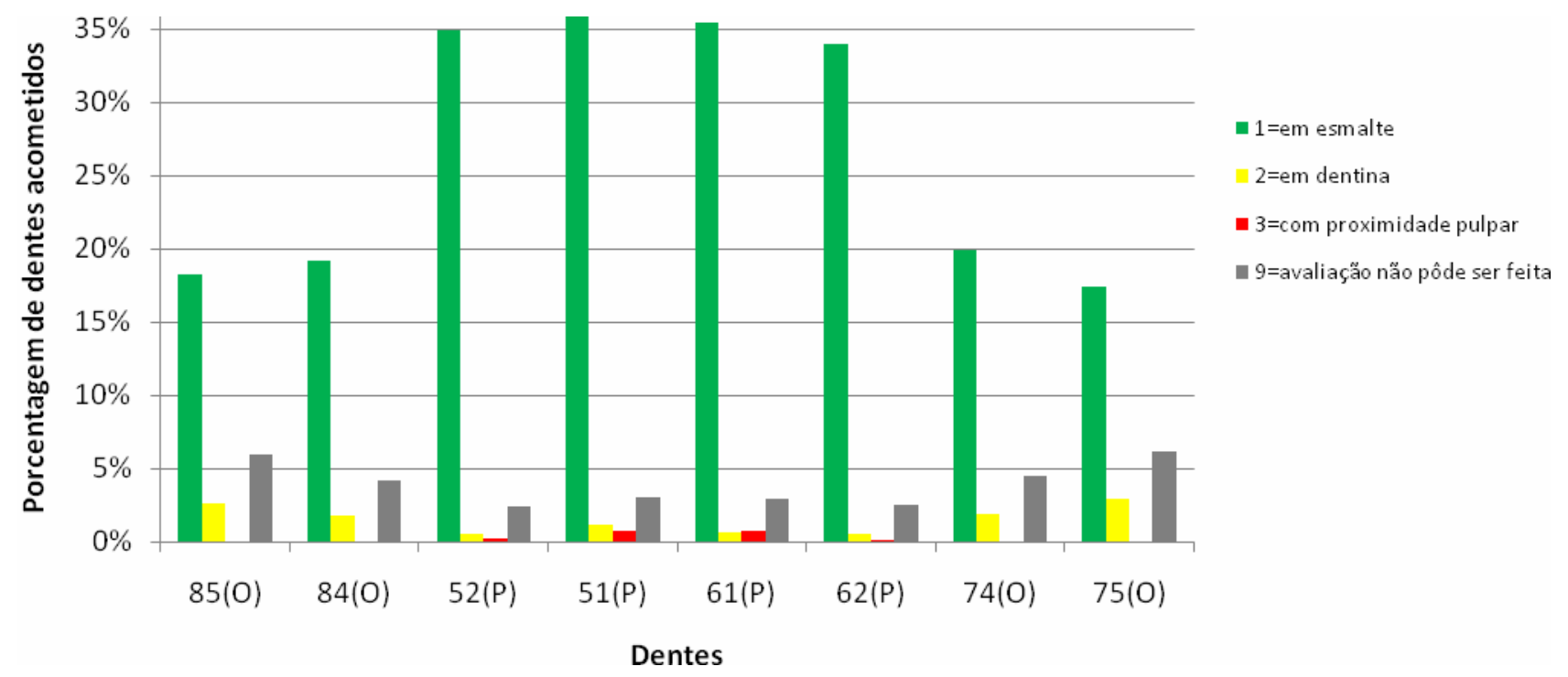

Gráfico 5.1 - Distribuição da porcentagem de dentes acometidos quanto ao grau de acometimento em profundidade de lesões erosivas, de acordo com o Índice de O'Brien (1994) Modificado. Diadema SP, 2008

O escore de profundidade mais comum foi o 1 , indicando uma maior ocorrência de lesões erosivas em esmalte em todos os dentes avaliados. As lesões em dentina (escore 2) foram mais frequentes nos molares do que nos incisivos. Além disso, neste estudo, as lesões que apresentavam desgaste com proximidade pulpar (escore 3) foram raras e foram encontradas exclusivamente nas palatinas de incisivos superiores. O escore 9 indica casos onde a profundidade da lesão erosiva não pôde ser avaliada devido à superfície estar inteiramente restaurada ou ao elemento dentário estar ausente.

O gráfico 5.2 ilustra a distribuição da porcentagem de dentes acometidos quanto ao grau de acometimento em área da superfície ocupada pela lesão erosiva. 


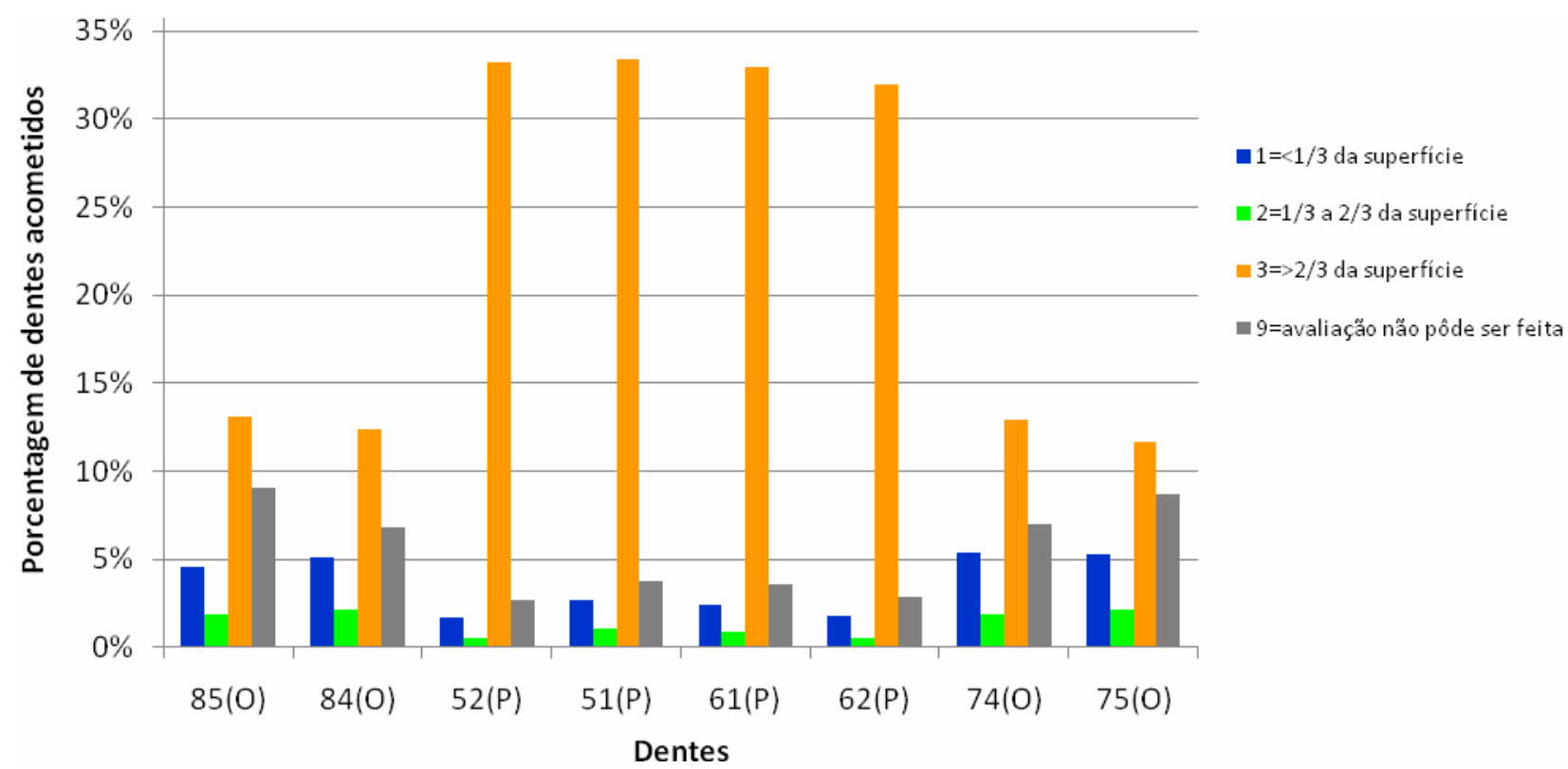

Gráfico 5.2 - Distribuição da porcentagem de dentes acometidos quanto ao grau de acometimento em área da superfície ocupada pela lesão erosiva, de acordo com o Índice de O'Brien (1994) Modificado. Diadema - SP, 2008

Observa-se neste gráfico que, na dentição decídua, as lesões erosivas que ocupam mais de $2 / 3$ da superfície dental (escore 3 ) são as mais frequentes tanto nas superfícies palatinas dos incisivos superiores quanto nas oclusais dos molares inferiores.. O segundo tipo de lesão erosiva mais frequentemente encontrado foi o que acomete até 1/3 da superfície avaliada (escore 1). Estas lesões, por sua vez, foram mais frequentes nos molares do que nos incisivos.

A tabela 5.4 contém os resultados da análise univariada dos dados da prevalência de erosão dentária e das variáveis analisadas: socioeconômicas, ambientais, nutricionais, comportamentais e relacionadas à criança. 
Tabela 5.4 - Análise de regressão univariada dos fatores socioeconômicos e nutricionais, variáveis relacionadas ao comportamento e às características da criança. Diadema - SP, 2008

\begin{tabular}{|c|c|c|c|c|}
\hline Variável Independente & $\begin{array}{c}\text { Sem Erosão } \\
\text { n(\%) }\end{array}$ & $\begin{array}{c}\text { Com Erosão } \\
n(\%)\end{array}$ & OR Bruto (IC $95 \%$ ) & $\mathbf{p}^{*}$ \\
\hline \multicolumn{5}{|c|}{ Bloco 1: Vartivels Socioeconomicas } \\
\hline Estruttra Familiar & & & & 0,482 \\
\hline Pai e mãe & $365(48,9)$ & $382(51,1)$ & & \\
\hline Familia reconstituida & $10(37,4)$ & $17(63.0)$ & $1.02(0.74-1.40)$ & \\
\hline Pai ou mấe solteira & $92(48,4)$ & $98(51,6)$ & $1,62(0,73-3,59)$ & \\
\hline Escolaridade da Mãe & & & & 0,808 \\
\hline Além do 1" grau & $259(48,1)$ & $279(51,9)$ & & \\
\hline Até o $11^{\circ}$ grau & $206(48,9)$ & $215(51,1)$ & $0,97(0,75-1,25)$ & \\
\hline Escolaridade do Pai & & & & 0,940 \\
\hline Além do $1^{\circ}$ grau & $209(48,3)$ & $224(51,7)$ & & \\
\hline Até o 1^grau & $205(31,6)$ & $222(52,0)$ & $1,01(0,77-1,32)$ & \\
\hline Renda Famillar & & & & 0,610 \\
\hline Năopossul & $31(43,7)$ & $40(56,3)$ & & \\
\hline Ate $2 \mathrm{sm}$ & $178(48,4)$ & $190(51,6)$ & $0,83(0,50-1,38)$ & \\
\hline Meis de 2 SM & $259(49,8)$ & $261(50,2)$ & $0,78(0,47-1,29)$ & \\
\hline \multicolumn{5}{|l|}{ Bloco 2: Varíáneds Amblantals } \\
\hline Aglomeraçāo domiciliar & & & & 0,917 \\
\hline$\leq 1$ pessoa por cốmodo & $268(48,6)$ & $283(51,4)$ & & \\
\hline >1 pessoa por cormodo & $199(48,3)$ & $213(51,7)$ & $1,01(0,79-1,31)$ & \\
\hline Tipo de moradia & & & & 0,961 \\
\hline Casa próprla & $292(48,5)$ & $310(51,5)$ & & \\
\hline Casa alugada & $175(48,3)$ & $187(51,7)$ & $1,01(0,78-1,31)$ & \\
\hline Número de filhos & & & & 0,948 \\
\hline 1 & $192(49,5)$ & $196(50,5)$ & & \\
\hline 2 & $152(48,3)$ & $163(51.8)$ & $1.05(0.78-1.41)$ & \\
\hline$\geq \mathbf{3}$ & $112(49,1)$ & $116(50,9)$ & $1,01(0,73-1,41)$ & \\
\hline \multicolumn{5}{|c|}{ Bloco 3: Vartavels Nutrictonais } \\
\hline Pesolidade & & & & 0,671 \\
\hline Adequado (entre-2e + 2) & $400(47,6)$ & $440(52,4)$ & & \\
\hline Inadequado $(<-2$ ou $>+2)$ & $44(50,0)$ & $44(50,0)$ & $0,91(0,59-1,41)$ & \\
\hline Altura/lade & & & & 0,119 \\
\hline $\begin{array}{l}\text { Adequado (entre }-2 e+2) \\
\text { Inadeguado }(<2 \text { ou }>+2)\end{array}$ & $\begin{array}{l}417(48,5) \\
25(38,5)\end{array}$ & $\begin{array}{l}443(51,5) \\
40(615)\end{array}$ & $151(0.9253)$ & \\
\hline MCNdade & & & $1,01(0,8-2,20)$ & 0,239 \\
\hline Adequado (entre $-2 e+2$ ) & $391(48,6)$ & $413(51,4)$ & & \\
\hline Inadequado $(<-2$ ou $>+2)$ & $51(42,9)$ & $68(57,1)$ & $1,26(0,86-1,86)$ & \\
\hline Pesolattura & & & & 0,412 \\
\hline Adequado (entre-2e + 2) & $390(48,6)$ & $413(51,4)$ & & \\
\hline Inadequado $(<-2$ ou $>+2)$ & $53(44,5)$ & $66(55.5)$ & $1,18(0,8-1,73)$ & \\
\hline \multicolumn{5}{|c|}{ Bloco 4: Vartavels comportamentals } \\
\hline \multicolumn{4}{|c|}{ Consumo de refirigerante nos últimos 2 dias } & $\mathbf{0 , 3 2 3}$ \\
\hline Nắ & $238(50,0)$ & $238(50,0)$ & & \\
\hline Sim & $228(46,8)$ & $259(53,2)$ & $1,14(0,88-1,46)$ & \\
\hline \multirow{2}{*}{\multicolumn{4}{|c|}{ Freqūôncia de ingestäo de refrigerantos }} & $0,023^{*}$ \\
\hline Nāotoma & $393(49,9)$ & $395(50,1)$ & & \\
\hline Uma vez por dia & $27(55.1)$ & $22(44.9)$ & $0.81(0.45-1.45)$ & \\
\hline Duas vezes por dia & $23(36,5)$ & $40(63,5)$ & $1,73(1,02-2,94)$ & \\
\hline Mels de tres vezes por dia & $23(35,4)$ & $42(64,6)$ & $1,82(1,07-3,08)$ & \\
\hline Temperatura do refrigerant: & & & & 0,465 \\
\hline Serngeto & $52(43,7)$ & $67(53,6)$ & & \\
\hline Gelado & $22(37,9)$ & $36(62,1)$ & $1,27(0,67-2,41)$ & \\
\hline Consumo de sucos nos dilti & 2 dias & & & $0,020^{*}$ \\
\hline Nāo & $103(56,0)$ & $81(44,0)$ & & \\
\hline Sim & $363(46,5)$ & $418(53,5)$ & $1,46(1,06-2,02)$ & \\
\hline Frequêncla de Ingestalo de: & & & & 0,083 \\
\hline Näo toma & $137(55,0)$ & $112(45,0)$ & & \\
\hline Uma vez por dia & $82(45,8)$ & $97(54,2)$ & $1,45(0,98-2,13)$ & \\
\hline Duas vezes por dia & $148(47,6)$ & $163(52,4)$ & $1,35(0,96-1,88)$ & \\
\hline Meis de três vezes por dia & $99(44,0)$ & $126(56,0)$ & $1,56(1,08-2,24)$ & \\
\hline Temperatura do suco & & & & 0,511 \\
\hline Semgelo & $272(45,4)$ & $327(54,6)$ & & \\
\hline Gelado & $5(48,7)$ & $60(51,3)$ & $0,88(0,59-1,30)$ & \\
\hline Regurgitaçäo freqüente & & & & 0,464 \\
\hline Năo & $437(48,6)$ & $462(51,4)$ & & \\
\hline Sim & $29(43,9)$ & $37(56,1)$ & $1,21(0,73-2,00)$ & \\
\hline Relluxogastroessoffigico rel & ido frequenle & & & $0,007^{*}$ \\
\hline Năo & $441(50,0)$ & $449(50.5)$ & & \\
\hline $\operatorname{Sim}$ & $25(33,3)$ & $50(66,7)$ & $1,96(1,19-3,23)$ & \\
\hline Blaco 5: Caracteristicas da & ancas & & & \\
\hline Sexo & & & & 0,914 \\
\hline Feminino & $241(48,4)$ & $256(51,5)$ & & \\
\hline Masculino & $220(48,1)$ & $297(51,9)$ & $1,01(0,79-1,31)$ & \\
\hline ldade (anos) & & & & $0,003^{*}$ \\
\hline 3 & $269(52,8)$ & $240(47,2)$ & & \\
\hline 4 & $199(43,4)$ & $259(56,6)$ & $1,46(1,13-1,88)$ & \\
\hline Presença de Placa & & & & \\
\hline Bacterlana & & & & 0,528 \\
\hline o & $200(46,51)$ & $230(53,5)$ & & \\
\hline 1 & $241(48,59)$ & $255(51,4)$ & $0,92(0,71-1,19)$ & \\
\hline Presenca de Cárie Dentária & & & & 0,240 \\
\hline 0 & $240(41,6)$ & $225(48,4)$ & & \\
\hline 1 & $118(47,0)$ & $133(53,0)$ & $1,20(0,88-1,64)$ & \\
\hline
\end{tabular}


Os resultados da análise de regressão univariada indicaram que as variáveis que representam os parâmetros socioeconômicos não foram associadas à prevalência de erosão dentária. Nenhum fator ambiental investigado teve associação estatisticamente significativa com a prevalência de erosão dentária. Com relação aos fatores nutricionais investigados, a prevalência de erosão dentária não foi estatisticamente diferente com relação ao peso/idade, altura/idade, IMC/idade e peso/altura inadequados nas crianças examinadas.

De acordo com a tabela 5.4 , crianças que consomem refrigerantes mais de três vezes ao dia apresentam 1,82 vezes mais chance de apresentarem erosão dentária (IC95\%: 1,07-3,08) quando comparadas àquelas que não consomem refrigerantes. Outro fator associado à ocorrência de lesões erosivas foi o consumo de suco nos dois últimos dias que antecederam a data da coleta de dados, de maneira que crianças que haviam consumido suco recentemente possuíam 1,46 mais chance de apresentar a doença (IC95\%: 1,06-2,02). Além disso, a prevalência de erosão dentária foi associada à presença de refluxo gastroesofágico relatado frequente. Crianças que apresentavam relatos deste distúrbio tinham 1,96 vezes mais chances de terem seus dentes desgastados por erosão dentária (IC95\%: 1,19$3,23)$.

Também foi possível observar que houve um aumento de 1,46 vezes na razão de chance de apresentar erosão dentária com o aumento da idade (IC95\%: 1,13-1,88).

Não houve associação estatisticamente significativa entre a presença de lesões erosivas e o sexo dos participantes e entre a presença de lesões erosivas e a presença de placa bacteriana na superfície vestibular dos incisivos superiores. 
Por fim, os resultados da análise da associação entre a prevalência de erosão dentária e a prevalência de cárie dentária também estão demonstrados na tabela 5.4. Para a análise da associação entre erosão e cárie, a amostra total foi de 716 crianças porque 251 crianças examinadas para erosão dentária não faziam parte da amostra coletada para o exame de cárie nesta faixa etária. Apesar da prevalência da erosão ter sido um pouco maior nas crianças com cárie, não houve associação estatística significativa $(p=0,240)$. A prevalência da erosão nas crianças com cárie foi de $53 \%$ e nas crianças sem cárie foi de $48,4 \%$.

A tabela 5.5 mostra o modelo final da análise de regressão multivariada hierárquica das variáveis associadas à prevalência de erosão dentária.

Tabela 5.5 - Modelo final da análise de regressão multivariada hierárquica dos fatores associados à prevalência de erosão dentária em crianças pré-escolares. Diadema - SP, 2008

\begin{tabular}{|c|c|c|c|}
\hline Variáveis & $\begin{array}{l}\text { OR Bruto } \\
\text { (IC95\%) }\end{array}$ & $\begin{array}{l}\text { OR Ajustado } \\
\text { (IC95\%) }\end{array}$ & $\begin{array}{l}\text { Valor de p } \\
\text { Ajustado }\end{array}$ \\
\hline \multicolumn{4}{|c|}{$4^{\circ}$ Bloco: Variáveis comportamentais } \\
\hline \multicolumn{4}{|c|}{ Frequência de consumo de refrigerantes } \\
\hline \multicolumn{4}{|c|}{ Não toma } \\
\hline Uma vez por dia & $0,81(0,45-1,45)$ & $0,78(0,43-1,40)$ & 0,402 \\
\hline Duas vezes por dia & $1,73(1,02-2,94)$ & $1,74(1,02-2,99)$ & $0,043^{*}$ \\
\hline Mais de três vezes por dia & $1,82(1,07-3,08)$ & $1,87(1,10-3,20)$ & $0,021^{*}$ \\
\hline \multicolumn{4}{|c|}{ Consumo de sucos nos últimos dois dias } \\
\hline \multicolumn{4}{|c|}{ Não } \\
\hline Sim & $1,46(1,06-2,02)$ & $1,55(1,11-2,16)$ & $0,009^{*}$ \\
\hline \multicolumn{4}{|c|}{ Refluxo gastroesofágico relatado frequente } \\
\hline \multicolumn{4}{|c|}{ Não } \\
\hline Sim & $1,96(1,19-3,23)$ & $2,06(1,24-3,41)$ & $0,005^{*}$ \\
\hline \multicolumn{4}{|c|}{$5^{\circ}$ Bloco: Características da criança } \\
\hline \multicolumn{4}{|l|}{ Idade } \\
\hline \multicolumn{4}{|l|}{3 anos } \\
\hline 4 anos & $1,46(1,13-1,88)$ & $1,48(1,15-1,92)$ & $0,003^{*}$ \\
\hline
\end{tabular}


Os resultados indicam que a prevalência de erosão dentária aumenta 2,06 vezes de acordo com a presença de refluxo relatado frequente (IC95\%: 1,23-3,41), 1,55 vezes de acordo com a ingestão de suco nos últimos dois dias (IC95\%:1,112,16), 1,74 vezes de acordo com a ingestão de refrigerantes 2x/dia (IC95\%:1,022,99), 1,87 vezes de acordo com a ingestão de refrigerantes 3x/dia (IC95\%: 1,103,20 ) e de acordo com o aumento da idade (IC95\%: 1,15-1,92). 


\section{DISCUSSÃO}

O presente trabalho diferencia-se dos demais estudos publicados sobre a prevalência de erosão dentária por ter sido realizado durante uma Campanha de Multivacinação, assegurando uma maior representatividade da população. Em 2006, na região sudeste do Brasil, $80,8 \%$ das crianças na faixa etária de $0-3$ anos e $37,6 \%$ das crianças de 4 anos de idade não frequentavam escola ou creche (IBGE, 2006). Assim sendo, a estratégia de coletar dados de crianças menores de 5 anos de idade durante o Dia Nacional de Vacinação tem por finalidade universalizar a amostra e minimizar erros de seleção, uma vez que permite que grande parte desta população esteja disponível para participar do estudo, solucionando a dificuldade relatada previamente de se examinar crianças nesta faixa etária em escolas (JONES; NUNN, 1995).

\subsection{Critérios de diagnóstico e classificação de lesões erosivas}

A comparação direta dos resultados obtidos no presente estudo com outros trabalhos publicados na literatura é dificultada pela utilização de diferentes critérios de diagnóstico e classificações de erosão dentária e pela diversidade de faixas etárias avaliadas nos diversos estudos. A dificuldade para se estabelecer critérios de diagnóstico precisos para a erosão dentária (GANSS; KLIMEK; GIESE, 2008) provém parcialmente do fato de que, na cavidade oral, a perda de estrutura dental por desgaste resulta de uma combinação dos processos de atrição, abrasão e 
erosão dentária que ocorrem simultaneamente (KAZOULLIS et al., 2007; O'BRIEN, 1994; PERES et al., 2005; WIEGAND et al., 2006).

Porém, é possível identificar o fator etiológico predominante do desgaste dental presente baseado da aparência clínica da lesão (GANDARA; TRUELOVE, 1999; RIOS et al., 2007). Além disso, em populações de crianças de pouca idade, a erosão dentária é responsável por grande parte dos desgastes evidenciados e pelo aumento da ocorrência de desgaste dental (AL-DLAIGAN; SHAW; SMITH 2001; JAEGGI; LUSSI, 2006). Portanto, no presente estudo somente o desgaste dental causado por erosão dentária foi investigado (AL-DLAIGAN; SHAW; SMITH, 2001).

O índice de O'Brien (1994) foi escolhido neste estudo por ter sido utilizado no Levantamento Nacional sobre Saúde Oral no Reino Unido (O'BRIEN, 1994) e por ter sido o índice mais comumente aplicado na dentição decídua (AL-MAJED; MAGUIRE; MURRAY, 2002; DESHPANDE; HUGAR, 2004; HINDS; GREGORY, 1995; JONES, NUNN, 1995; LUO et al., 2005; O'BRIEN, 1994). Além disso, é um índice de fácil aplicação em crianças (AL-MAJED; MAGUIRE; MURRAY, 2002; DUGMORE; ROCK, 2004a; LUO et al., 2005; AUAD et al., 2007). Este índice é também bastante completo uma vez que designa um código para descrever a profundidade da lesão erosiva encontrada e um código para representar a área de extensão da lesão.

No estudo realizado por O'Brien (1994), o autor relatou dificuldade de obter concordância entre os examinadores com relação às lesões erosivas em esmalte durante a calibração. Entretanto, quando este mesmo índice foi utilizado em outros estudos (AL-MAJED; MAGUIRE; MURRAY, 2002; DEERY et al. 2000; DUGMORE; ROCK, 2004b; LUO et al., 2005; WILLIAMS et al., 1999), bons índices de concordância intra e interexaminadores foram obtidos. Semelhantemente, no 
presente estudo, bons índices de concordância intra e interexaminadores foram obtidos (Tabela 4.1) e não houve dificuldade com relação ao diagnóstico de estágios iniciais de erosão dentária e à diferenciação entre lesões erosivas em esmalte e em dentina.

A borda incisal dos incisivos decíduos foi excluída da análise devido ao fato de esta ser particularmente sujeita ao desgaste por atrição (LUO et al., 2005; MATHEW; CASAMASSIMO; HAYES, 2002; MILLWARD; SHAW; SMITH, 1994), podendo gerar incertezas sobre o critério de diagnóstico (AL-MAJED; MAGUIRE; MURRAY, 2002; GANSS; KLIMEK; GIESE, 2001).

Com relação à utilização de dentes índices, o diagnóstico e a avaliação da gravidade de lesões erosivas é um processo que consome tempo. Além da avaliação parcial da cavidade oral viabilizar a aplicação do índice de O'Brien (1994) em estudos populacionais em larga escala, Truin et al. (2005) comprovaram que somente uma perda mínima é observada ao se comparar resultados de prevalência de erosão dentária obtidos em avaliações de todos os dentes com aqueles obtidos em avaliações de dentes índices. Portanto, neste estudo, os incisivos superiores e os primeiros molares inferiores decíduos foram examinados por serem estes os elementos dentais mais comumente acometidos pela erosão dentária e mais frequentemente utilizados como índices (AUAD et al., 2007; DESHPANDE; HUGAR, 2004; EL-AIDI; BRONKHORST; TRUIN, 2008; JENSDOTTIR et al., 2004; KAZOULLIS et al., 2007; LARSEN; POULSEN; HANSEN, 2005).

A superfície palatina dos incisivos foi escolhida para avaliação por ser mais comumente acometida por erosão dentária do que a vestibular (AUAD et al., 2007; CHADWICK; PENDRY, 2003; JONES; NUNN, 1995; NUNN et al., 2003; PERES et al., 2005). Semelhantemente, a superfície oclusal dos primeiros molares inferiores 
foi selecionada para o exame por apresentar lesões erosivas mais frequentemente do que a oclusal dos molares superiores (AL-MAJED; MAGUIRE; MURRAY, 2002; CHADWICK; PENDRY, 2003; EL-AIDI; BRONKHORST; TRUIN, 2008).

\subsection{Prevalência, distribuição e gravidade das lesões erosivas}

Quando comparada com estudos epidemiológicos que incluíram a faixa etária entre 36 e 59 meses de idade, a prevalência de erosão dentária encontrada no município de Diadema foi maior do que a encontrada no Reino Unido de $19-29 \%$, na Arábia Saudita de 31\%, na Alemanha de 32\% e na China de 5,7\% (Tabela 2.1). De acordo com Luo et al. (2005), um dos motivos que explica a baixa prevalência de erosão dentária encontrada na China, quando comparada a outros países, pode ser o baixo consumo per capita de bebidas ácidas, de somente 8 litros por ano. Por contraparte, no Brasil, o consumo per capita de refrigerantes é de 81 litros por ano (ABIR, 2009).

Porém, considerando-se que a maioria dos estudos encontrou uma prevalência de erosão dentária de $30 \%$ ou mais nesta faixa etária (AL-MALIK; HOLT; BEDI, 2001; JONES; NUNN, 1995; MILLWARD et al., 1994; MILLWARD; SHAW; SMITH, 1994; WALKER et al., 2000; WIEGAND et al., 2006), a prevalência observada no município de Diadema não diverge muito dos achados prévios. Adicionalmente, Millward, Shaw e Smith (1994) encontraram uma prevalência, 
condizente com os resultados do presente estudo, de $50 \%$ entre crianças de $4-5$ anos de idade na Inglaterra.

Alguns outros motivos que podem explicar as divergências nas prevalências encontradas nestes diferentes estudos são: a utilização de diferentes critérios de diagnóstico de erosão dentária, diferenças socioeconômicas, culturais e demográficas entre os diferentes países estudados e a avaliação de diferentes dentes (DE CARVALHO SALES-PERES et al., 2008; KAZOULLIS et al., 2007; PERES et al., 2005; WIEGAND et al., 2006).

Até o presente momento, ainda não existem dados publicados sobre a prevalência de erosão dentária em crianças pré-escolares brasileiras, porém há cinco estudos em escolares (AUAD et al., 2007; DE CARVALHO SALES-PERES et al., 2008; MANGUEIRA; SAMPAIO; OLIVEIRA, 2009; PERES et al., 2005; RIOS et al., 2007). Nestes, a prevalência variou entre 13\% (PERES et al., 2005) e 34,1\% (AUAD et al., 2007).

Com relação à distribuição das lesões erosivas observadas no presente estudo, estas foram mais frequentes nos incisivos superiores do que nos primeiros molares inferiores decíduos, o que condiz com achados de outros trabalhos que utilizaram estes mesmos dentes índices porém na dentição permanente (AUAD et al., 2007; JENSDÓTTIR et al., 2004; MCGUIRE et al., 2009). Uma explicação para este fato pode ser que as superfícies oclusais dos molares apresentaram restaurações ou lesões extensas de cárie que impediram a avaliação do elemento (escore 9) com maior frequência do que as palatinas dos incisivos (AUAD et al., 2007). Houve também uma tendência à bilateralidade e à simetria no padrão de acometimento por erosão dentária das arcadas direita e esquerda (Gráfico 5.1), 
tanto nos incisivos quanto nos molares, como também relatado previamente na literatura (DUGMORE; ROCK, 2004b; JONES; NUNN, 1995; MILLWARD et al., 1994; WIEGAND et al., 2006).

A respeito da gravidade das lesões erosivas, a profundidade de lesão mais comumente encontrada em todos os dentes neste e em grande parte dos estudos sobre prevalência de erosão conduzidos em ambas as dentaduras decídua e permanente foi o escore 1 (Gráfico 5.1), correspondente a lesões iniciais em esmalte (AL-DLAIGAN; SHAW; SMITH, 2001; BORCIC et al., 2004; CHADWICK; PENDRY, 2003; DE CARVALHO SALES-PERES et al., 2008; DUGMORE; ROCK, 2004b; ELKARIM et al., 2007; MILLWARD et al., 1994; WIEGAND et al., 2006).

O papel protetor que a saliva exerce sobre o processo de progressão de lesões erosivas devido à sua capacidade tampão, à formação de película adquirida e ao seu potencial remineralizador pode oferecer uma explicação para a maior ocorrência de lesões erosivas graves, com proximidade pulpar, nas superfícies palatinas dos incisivos superiores em comparação com superfícies oclusais dos molares inferiores. O fluxo salivar na região palatina dos incisivos superiores é reduzido em comparação com o fluxo na região dos molares inferiores e alguns estudos laboratoriais já comprovaram a existência de uma relação entre a presença de saliva e a especificidade de sítios de instalação e progressão de lesões erosivas dentro da cavidade bucal (AMAECHI et al., 1999; AMAECHI; HIGHAM, 2001; YOUNG; KHAN, 2002).

Além desta, outra explicação para a ocorrência mais frequente de lesões erosivas graves nos incisivos superiores do que nos molares inferiores pode estar na cronologia de erupção. Devido ao fato de os incisivos superiores decíduos 
erupcionarem aproximadamente um ano antes dos molares inferiores, os incisivos estavam expostos aos desafios erosivos na cavidade oral das crianças examinadas há mais tempo.

Com relação à gravidade em termos de área acometida pela lesão, o escore 3, correspondente às lesões que ocupam mais de $2 / 3$ da superfície sendo avaliada foi o mais comum (gráfico 5.2). Este achado era esperado pois, na maioria das vezes, as lesões erosivas iniciais são maiores em área do que em profundidade e ocupam mais de 2/3 da superfície (GANDARA; TRUELOVE, 1999; O'BRIEN, 1994). Nos molares, as lesões também podem se iniciar como cuppings, ocupando menos de 1/3 da área da superfície oclusal, o que foi confirmado pela ocorrência maior de escore 1 em molares do que em incisivos neste estudo. De maneira geral, a gravidade das lesões erosivas em crianças pré-escolares em Diadema foi leve.

\subsection{Variáveis associadas à ocorrência de erosão dentária}

A investigação do impacto de variáveis socioeconômicas na saúde bucal é de grande importância. Fatores como a renda familiar, o nível de escolaridade e as condições de moradia podem estar associados à maior ou menor ocorrência de doenças por influenciarem o acesso a informações sobre cuidados bucais, o valor atribuído à saúde bucal e o estilo de vida e comportamentos de risco para a saúde bucal dos indivíduos (HAMASHA et al., 2006; SABBAH et al., 2009). Evidências 
científicas mostram que, dentro de sociedades desenvolvidas ou em desenvolvimento, quanto mais baixo for o padrão de vida material, pior será o nível de saúde da população, independentemente do indicador utilizado (OLIVEIRA, 2006; SABBAH et al., 2009).

No presente estudo, não foi encontrada associação estatisticamente significativa entre a prevalência de erosão dentária e o nível socioeconômico (Tabela 5.4) das crianças avaliadas. Semelhantemente, alguns estudos prévios também não encontraram uma associação significativa entre a prevalência de erosão dentária e níveis socioeconômicos (AL-MAJED; MAGUIRE; MURRAY, 2002; AL-MALIK; HOLT; BEDI, 2001; AUAD et al., 2007; DUGMORE; ROCK, 2004b; TRUIN et al., 2005). A amostra utilizada neste estudo oferece uma boa representatividade da população e homogeneidade. Assim sendo, um dos motivos pelo qual não foi encontrada associação significativa entre a prevalência de erosão dentária e as variáveis socioeconômicas estudadas pode ser o fato de que a população estudada é originária de uma cidade com indicadores sociais baixos. Poucas famílias recebem salários superiores a $R \$ 2.000,00$ e poucos chefes de família possuem um nível de escolaridade universitário em Diadema (OLIVEIRA, 2006).

Em outros estudos, enquanto alguns autores relataram que a erosão dentária foi mais prevalente entre indivíduos de níveis socioeconômicos mais baixos (ALDLAIGAN; SHAW; SMITH, 2001; EL-AIDI; BRONKHORST; TRUIN, 2008; HARDING et al., 2003; JONES, NUNN, 1995; KAZOULLIS et al., 2007; MILOSEVIC; YOUNG; LENNON, 1994; NUNN et al., 2003), outros relataram o inverso (BARDSLEY et al., 2004; LUO et al., 2005; MANGUEIRA; SAMPAIO; OLIVEIRA, 2009; MILLWARD; SHAW; SMITH, 1994; PERES et al., 2005; WILLIAMS et al., 1999). A maioria destes 
autores simplesmente cita se houve ou não associação entre erosão dentária e níveis socioeconômicos sem oferecer explicações para os achados.

Um dos únicos autores que oferece uma explicação para a maior prevalência associada a níveis socioeconômicos inferiores justifica este fato pela falta de conscientização desta população com relação aos malefícios que as bebidas ácidas podem causar à saúde bucal (KAZOULLIS et al., 2007). Com relação à maior prevalência de erosão dentária entre indivíduos de níveis socioeconômicos elevados, uma das explicações dadas foi que maiores níveis de escolaridade e melhores condições socioeconômicas podem influenciar o estilo de vida e os hábitos alimentares, gerando um maior consumo de bebidas gaseificadas (LUO et al., 2005; PERES et al., 2005).

A aglomeração domiciliar, o tipo de moradia e o número de filhos que os pais da criança têm podem influenciar na ocorrência de problemas bucais em populações infantis (MOYSÉS; RODRIGUES, 2004). Bönecker (2005) verificou em Diadema que para cada filho a mais que a mãe possuía, a chance de a criança participante ter cárie aumentava na razão de 1,174. Entretanto, com relação à erosão dentária, nenhuma associação significante foi observada com as variáveis ambientais investigadas (Tabela 5.4). Nenhum outro estudo sobre a prevalência de erosão dentária na literatura analisou a associação desta patologia com fatores ambientais, impossibilitando a comparação dos resultados obtidos no presente estudo.

O estado nutricional de um indivíduo pode influenciar no seu desenvolvimento e na sua predisposição a doenças. Seguindo o raciocínio de que as doenças sistêmicas e orais possuem fatores de risco comuns (SHEIHAM; BÖNECKER, 2006), torna-se plausível investigar se há associação entre a ocorrência de erosão 
dental e o estado nutricional da criança, uma vez que ambos são afetados por hábitos alimentares. Pouco se pesquisa sobre a associação entre a erosão dentária e o estado nutricional, porém na literatura Odontológica há estudos investigando se existe a associação do estado nutricional à cárie dentária (OLIVEIRA, 2006; ZARDETTO, 2004).

A comparação dos resultados obtidos neste estudo é dificultada pelo fato de que, até o presente momento, somente McGuire et al. (2009) investigaram a associação entre a prevalência de erosão dentária e o estado nutricional da criança. Os resultados da análise univariada (Tabela 5.4) mostram que não houve associação significativa entre a prevalência de erosão dentária e o estado nutricional das crianças na população examinada, o que está de acordo com os achados de McGuire et al. (2009).

Os resultados indicam a existência de uma associação significativa entre a prevalência de erosão dentária na população estudada e o consumo frequente de refrigerantes mais de duas $(p=0,043)$ ou mais de três $(p=0,021)$ vezes ao dia. A relação entre a ingestão de bebidas carbonatadas e a ocorrência de erosão dentária já está bem estabelecida na literatura e este achado está de acordo com o de alguns estudos (AL-MAJED; MAGUIRE; MURRAY, 2002; AL-MALIK; HOLT; BEDI, 2001; HARDING et al., 2003; HINDS; GREGORY, 1995; MILLWARD et al., 1994; NUNN et al., 2003).

A pergunta sobre o consumo de bebidas ácidas nos últimos dois dias que antecederam a data da coleta foi inserida no questionário com o intuito de diminuir o viés de memória. Comumente, o responsável responde que a criança não ingere bebidas ácidas todos os dias, porém também relata que ela ingeriu bebidas ácidas 
nos últimos dois dias. Assim sendo, apesar de a ingestão diária de sucos não ter mostrado associação significante com a prevalência de erosão dentária, esta prevalência foi maior entre crianças que haviam bebido suco nos últimos dois dias $(p=0,009)$. Este resultado também corrobora com os achados de estudos prévios sobre a ingestão diária de sucos e a ocorrência de erosão dentária (AL-MALIK; HOLT; BEDI, 2001; HARDING et al., 2003; LUO et al., 2005; MILLWARD et al., 1994).

Outra variável pesquisada foi o RGR. Uma forte associação $(p=0,005)$ foi encontrada entre a presença de refluxo gastroesofágico relatado (RGR) frequente e a prevalência de erosão dentária no presente estudo. Enquanto nas crianças sem RGR a prevalência de erosão dentária foi de $50,5 \%$, entre crianças com RGR a prevalência foi de $66,7 \%$ (Tabela 5.4). Este resultado está de acordo com o estudo de Nunn et al. (2003) que reportou uma prevalência significantemente maior entre crianças de 4 a 6 anos de idade que apresentavam RGR, em comparação com crianças sem RGR.

Os resultados não mostraram diferenças significativas da prevalência de erosão dentária entre meninos e meninas (Tabela 5.1) e estão de acordo com os achados de outros estudos (AUAD et al., 2007; DEERY et al., 2000; HARDING et al., 2003; JENSDÓTTIR et al., 2004; KAZOULLIS et al., 2007; LUO et al., 2005; NUNN et al., 2003; PERES et al., 2005; WIEGAND et al., 2006).

Nos estudos em que foi encontrada uma associação significativa com o sexo, a erosão dentária foi mais prevalente no sexo masculino do que no feminino (ALDLAIGAN; SHAW; SMITH, 2001; ÁRNADÓTTIR; SAEMUNDSSON; HOLBROOK, 2003; BARDSLEY et al., 2004; DUGMORE; ROCK, 2004b; LARSEN; POULSEN; 
HANSEN, 2005; MANGUEIRA; SAMPAIO; OLIVEIRA, 2009; MCGUIRE et al., 2009; MILOSEVIC; YOUNG; LENNON, 1994; TRUIN et al., 2005). Alguns estudos citam, como motivos para esta diferença, o consumo mais frequente de bebidas ácidas por meninos (ÁRNADÓTTIR; SAEMUNDSSON; HOLBROOK, 2003; BARDSLEY et al., 2004) e a maior força muscular mastigatória de meninos, que pode causar maior atrição e abrasão da estrutura dental erodida (BARDSLEY et al., 2004).

Em um dos únicos estudos longitudinais conduzidos sobre a erosão dentária, a diferença de prevalência entre os sexos não foi significativa no exame inicial, mas foi significativamente maior entre meninos na reavaliação após um ano e meio (ELAIDI; BRONKHORST; TRUIN, 2008). A prevalência de erosão dentária só foi maior em meninas do que em meninos em dois estudos (KÜNZEL; CRUZ; FISCHER, 2000; MILOSEVIC; YOUNG; LENNON, 1994), porém os autores não elucidam o motivo.

No que diz respeito à idade dos participantes, uma prevalência significantemente maior de erosão dentária foi observada entre crianças de 4 anos do que entre as de 3 anos (Tabela 5.5). A grande maioria dos estudos conduzidos em crianças revelou que a prevalência de erosão dentária aumenta significantemente com o aumento da idade (CHADWICK; PENDRY, 2003; MCGUIRE et al., 2009; NUNN et al., 2003; O‘BRIEN, 1994; WIEGAND et al., 2006). Tal aumento na prevalência deve-se, em parte, à natureza cumulativa da perda por desgaste erosivo da estrutura dental, que raramente é restaurada em estágios iniciais. Quando a erosão dentária não é diagnosticada precocemente e não ocorre uma eliminação ou diminuição da exposição dos dentes ao fator etiológico, tanto a ocorrência quanto a gravidade das lesões erosivas tendem naturalmente a aumentar com o decorrer do tempo. 
A associação entre a prevalência de erosão dentária e a de cárie dentária tem sido alvo de indagação devido ao fato de ambas as patologias possuírem fatores de risco em comum, sendo causadas por ácidos e por hábitos alimentares inadequados. Apesar disso, os resultados do presente estudo indicaram que não houve diferença estatisticamente significativa $(p=0,240)$. A prevalência de erosão foi semelhante entre crianças com (53\%) e sem (48\%) lesões de cárie, o que corrobora com achados de estudos prévios (AL-MALIK; HOLT; BEDI, 2001; KÜNZEL; CRUZ; FISCHER, 2000; TRUIN et al., 2005; VAN RIJKOM et al., 2002).

O presente estudo foi o primeiro a investigar, em uma amostra representativa da população, se a presença de placa bacteriana está associada à prevalência de erosão dentária em crianças pré-escolares. Apesar de resultados de estudos experimentais (CHEUNG et al., 2005; JOHANSSON; LINGSTRÖM; BIRKHED, 2002) terem indicado a possibilidade de a placa bacteriana constituir um fator protetor contra a erosão dentária, no presente estudo não houve associação estatisticamente significativa entre presença de placa e ausência de erosão. 


\section{CONCLUSÕES}

A prevalência de erosão dentária encontrada nesta população de crianças pré-escolares foi alta, mais frequente em incisivos superiores e de gravidade leve.

Os indicadores de risco associados à prevalência de erosão dentária em crianças pré-escolares de Diadema foram: os hábitos alimentares de ingestão frequente de refrigerantes e ingestão recente de sucos ácidos, a presença de refluxo gastroesofágico relatado frequente e o aumento de idade 


\section{REFERÊNCIAS ${ }^{1}$}

Abreu FGV de. Cárie dentária e estado nutricional em pré-escolares na zona periurbana de Santos Dummont - Minas Gerais [Tese de Doutorado]. Rio de Janeiro: Faculdade de Odontologia da UFRJ; 1999.

Aine L, Baer M, Mäki M. Dental erosion caused by gastroesophageal reflux disease in children. J Dent Child 1993; 60(3): 210-4.

Alaluusua S, Malmivirta R. Early plaque accumulation--a sign for caries risk in young children. Community Dent Oral Epidemiol 1994;22(5):273-6.

Al-Dlaigan Y, Shaw L, Smith A. Dental erosion in a group of British 14-year-old, school children. Part I: Prevalence and influence of differing socioeconomic backgrounds. Br Dent J 2001;190(3):145-9.

Al-Majed I, Maguire A, Murray J. Risk factors for dental erosion in 5-6 year old and 12-14 year old boys in Saudi Arabia. Community Dent Oral Epidemiol 2002;30(1):3846.

Al-Malik MI, Holt RD, Bedi R. The relationship between erosion, caries and rampant caries and dietary habits in preschool children in Saudi Arabia. Int J Paediatr Dent 2001;11(6):430-9.

Alvarez JO, Caceda J, Wooley TW, Carley KW, Baiocchi N, Caravedo L, et al. A longitudinal study of dental caries in the primary teeth of children who suffered from infant malnutrition. J Dent Res 1993; 72(12): 1573-6.

\footnotetext{
${ }^{1}$ De acordo com Estilo Vancouver. Abreviatura de periódicos segundo base de dados MEDLINE.
} 
Alvarez JO, Eguren JC, Caceda J, Navia JM. The effect of nutritional status on the age distribution of dental caries in the primary teeth. J Dent Res 1990;69(9):1564-6.

Alvarez JO, Lewis CA, Saman C, Caceda J, Montalvo J, Figueroa ML, et al. Chronic malnutrition, dental caries, and tooth exfoliation in Peruvian children aged 3-9 years. Am J Clin Nutr 1988; 48(2): 368-72.

Amaechi BT, Higham SM. Eroded enamel lesion remineralization by saliva as a possible factor in the site-specificity of human dental erosion. Arch Oral Biol 2001; 46: 697-703.

Amaechi BT, Higham SM, Edgar WM, Milosevic A. Thickness of acquired salivary pellicle as a determinant of the sites of dental erosion. J Dent Res 1999; 78(12): $1821-8$.

Ardenghi TM. Associação entre a experiência de cárie dentária na região ânterosuperior e região posterior da dentição decídua em crianças de 5 a 59 meses de idade. Município de Diadema, São Paulo [Dissertação de Mestrado]. São Paulo: Faculdade de Odontologia da USP; 2003.

Ardenghi TM, Bönecker M, Tollara MN. Importância do banco de dentes humanos na etapa de calibração de estudos epidemiológicos. In: Imparato JCP. Banco de dentes humanos. $1^{1}$ ed . Curitiba: Editora Maio; 2003. Cap. 12; p.164-72.

Arnadóttir IB, Saemundsson SR, Holbrook P. Dental erosion in Icelandic teenagers in relation to dietary and lifestyle factors. Acta Odontol Scand 2003; 61(1): 25-8.

Associação Brasileira das Indústrias de Refrigerantes e Bebidas Não Alcoólicas. (ABIR) - Disponível em: URL: http://www.abir.org.br [20 set 2009].

Auad S, Waterhouse P, Nunn J, Steen N, Moynihan P. Dental erosion amongst 13and 14-year-old Brazilian schoolchildren. Int Dent J 2007; 57(3):161-7. 
Bardsley PF. The evolution of tooth wear indices. Clin Oral Invest 2008; 12(1): S15S19.

Bardsley P, Taylor S, Milosevic A. Epidemiological studies of tooth wear and dental erosion in 14-year-old children in North West England. Part 1: The relationship with water fluoridation and social deprivation. Br Dent J 2004; 197(7):413-6

Bartlett D, Dugmore C. Pathological or physiological wear - is there a relationship to age? Clin Oral Invest 2008; 12(1): S27-S31.

Bartlett D, Ganss C, Lussi A. Basic Erosive Wear Examination (BEWE): a new scoring system for scientific and clinical needs. Clin Oral Invest 2008; 12(1): S65S68.

Berg-Beckhoff G, Kutschmann M, Bardhle D. Methodological considerations concerning the development of oral dental erosion indexes: literature survey, validity and reliability. Clin Oral Invest 2008; 12(1): S51-S58.

Bönecker M. Análise comparativa de estudos epidemiológicos de cárie dentária em crianças de 5 a 59 meses de idade do município de Diadema, São Paulo, Brasil 1995 e 1997 [Tese de Doutorado ]. São Paulo: Faculdade de Odontologia da USP; 1999.

Bönecker M. Tendência da experiência de cárie em crianças de 5 a 59 meses de idade do município de Diadema (SP) entre os anos de 1995 e 2004 [Tese de LivreDocência]. São Paulo: Faculdade de Odontologia da USP; 2005.

Bonini GAVC. Estudo da tendência das lesões dentárias traumáticas em crianças de 5 a 59 meses de idade. Diadema - São Paulo. [Tese de Doutorado]. São Paulo: Faculdade de Odontologia da USP; 2008.

Borcic J, Anic I, Urek M, Ferreri S. The prevalence of non-carious cervical lesions in permanent dentition. J Oral Rehabil 2004;31(2):117-23. 
Chadwick B, Pendry L. Children's Dental Health in the United Kingdom, 2003 - Noncarious dental conditions. National Statistics [serial on the Internet] 2003. Disponível em:URL: http://www.statistics.gov.uk/children/dentalhealth/downloads/cdh noncarious dental decay.pdf. [02 jul 2009].

Cheung A, Zid Z, Hunt D, Mclntyre J. The potential for dental plaque to protect against erosion using an in vivo-in vitro model - a pilot study. Aust Dent J 2005; 50(4): 228-34.

Cleaton-Jones P, Hargreaves JA, Fatti LP, Chandler HD, Grossman ES. Dental caries diagnosis calibration for clinical field surveys. Caries Res 1989; 23(3): 195-9.

Corrêa MSNP, Begosso MP, Nassif ACS. Perimólise, Anorexia e Bulimia: Aspectos Clínicos e Psicológicos. In: Sucesso no atendimento odontopediátrico - Aspectos Psicológicos, São Paulo: Livraria Santos Editora Ltda, 2002, p.511-7

Darby ET. Dental erosion and the gouty diathesis: are they usually associated? The Dental Cosmos: a monthly record of dental science 1892; Vol. XXXIV: 629-40.

Dahshan A, Patel H, Delaney J, Wuerth A, Thomas R, Tolia V. Gastroesophageal reflux disease and dental erosion in children. J Pediatr 2002; 140(4): 474-8.

de Carvalho Sales-Peres S, Goya S, de Araújo J, Sales-Peres A, Lauris J, Buzalaf M. Prevalence of dental wear among 12-year-old Brazilian adolescents using a modification of the tooth wear index. Public Health 2008;122(9):942-8.

Deery C, Wagner ML, Longbottom C, Simon R, Nugent ZJ. The prevalence of dental erosion in a United States and a United Kingdom sample of adolescents. Pediatr Dent 2000; 22(5): 505-10.

Deshpande SD, Hugar SM. Dental erosion in children: an increasing clinical problem. J Indian Soc Pedod Prev Dent 2004; 22(3): 118-127. 
Downer MC. The 1993 national survey of children's dental health. Brit Dent J 1995; 178(11): 407-412.

Dugmore $\mathrm{C}$, Rock W. A multifactorial analysis of factors associated with dental erosion. Br Dent J 2004(a); 196(5):283-6.

Dugmore C, Rock W. The prevalence of tooth erosion in 12-year-old children. $\mathrm{Br}$ Dent J 2004(b); 196(5):279-82.

Eccles JD. Dental erosion of non-industrial origin. A clinical survey and classification. J Prosthet Dent 1979; 42(6): 649-53.

El-Aidi $\mathrm{H}$, Bronkhorst $\mathrm{E}$, Truin $\mathrm{G}$. A longitudinal study of tooth erosion in adolescents. J Dent Res 2008; 87(8):731-5.

El-Karim A, Sanhouri NM, Hashim NT, Ziada HM. Dental erosion among 12-14 year old school children in Khartoum: a pilot study. Community Dent Health 2007; 24(3): 176-80.

Ersin NK, Onçag O, Tümgör G, Aydogdu S, Hilmioglu S. Oral and dental manifestations of gastroesophageal reflux disease in children: a preliminary study. Pediatr Dent 2006; 28(3): 279-84.

Freire MCM. Políticas públicas de alimentação saudável. In: Bönecker M, Sheiham A. Caderno de Odontopediatria - Promovendo saúde bucal na infância e adolescência: conhecimentos e práticas. São Paulo: Editora Santos, 2004;p.109-31.

Gandara BK, Truelove EL. Diagnosis and management of dental erosion. J Contemp Dent Pract 1999; 1(1): 16-23.

Ganss $C$. How valid are current diagnostic criteria for dental erosion? Clin Oral Invest 2008; 12(1): S41-S49. 
Ganss C, Klimek J, Giese K. Dental erosion in children and adolescents - a crosssectional and longitudinal investigation using study models. Community Dent Oral Epidemiol 2001; 29(4): 264-271.

Glendor U. Aetiology and risk factors related to traumatic dental injuries - a review of the literature. Dent Traumatol 2009; 25(1): 19-31.

Gruebbel AO. A measurement of dental caries prevalence and treatment service for deciduous teeth. J Dent Res 1944; 23(3): 163-8.

Hamasha AA, Warren JJ, Levy SM, Broffitt B, Kanellis MJ. Oral health behaviors of children in low and high socioeconomic status families. Pediatr Dent 2006; 28(4): 310-5.

Harding M, Whelton H, O'Mullane D, Cronin M. Dental erosion in 5-year-old Irish school children and associated factors: a pilot study. Community Dent Health 2003; 20(3):165-70.

Hinds K, Gregory J. National Diet and Nutrition Survey: children aged 11/2 to $4 \frac{1}{2}$ years. Office of population censuses and surveys. London: HMSO; 1995.

IBGE. Diretoria de Pesquisas, Coordenação de Trabalho e Rendimento, Pesquisa Nacional por Amostra Domiciliar, 2006. Disponível em: URL:

http://www.ibge.gov.br/home/estatistica/populacao/trabalhoerendimento/pnad2004/s uplemento educacao/defaulttab.shmt [02 jul 2009].

IBGE. Instituto Brasileiro de Geografia e Estatística. Disponível em: URL: http://www.ibge.gov.br. [02 jul 2009].

Imfeld T. Dental erosion. Definition, classification and links. Eur J Oral Sci 1996; 104: 151-244. 
Jaeggi T, Lussi A. Prevalence, Incidence and Distribution of Erosion. Monogr Oral Sci 2006; 20: 44-65.

Jarman B. Identification of under privileged areas. Br Med J 1983; 286: 1705-1709.

Järvinen V, Rytömaa I, Meurman JH. Location of dental erosion in a referred population. Caries Res 1992; 26(5): 391-6.

Jensdottir T, Arnadottir I, Thorsdottir I, Bardow A, Gudmundsson K, Theodors A, et al. Relationship between dental erosion, soft drink consumption, and gastroesophageal reflux among Icelanders. Clin Oral Investig 2004; 8(2):91-6.

Johansson AK, Lingström $\mathrm{P}$, Birkhed D. Comparison of factors potentially related to the occurrence of dental erosion in high- and low-erosion groups. Eur J Oral Sci 2002; 110: 204-11.

Jones SG, Nunn JH. The dental health of 3-year-old children in east Cumbria. Community Dent Health 1995; 12(3): 161-6.

Jornal do Brasil. Disponível em URL:

http://www.jb.com.br/jb/papel/colunas/quedelícia/2005/04/09 [02 jul 2009].

Kazoullis S, Seow W, Holcombe T, Newman B, Ford D. Common dental conditions associated with dental erosion in schoolchildren in Australia. Pediatr Dent 2007; 29(1):33-9.

Kirkwood BR. Essentials of medical statistic. Oxford: Blackwell Scientific Publications, 1988; p.171.

Knutson JW. An index of the prevalence of dental caries in school children. Public Health Rep 1944; 59(8): 253-63. 
Künzel W, Cruz MS, Fischer T. Dental erosion in Cuban children associated with excessive consumption of oranges. Eur J Oral Sci 2000; 108(2): 104-9.

Larsen M, Poulsen S, Hansen I. Erosion of the teeth: prevalence and distribution in a group of Danish school children. Eur J Paediatr Dent 2005;6(1):44-7.

Linnett V, Seow WK. Dental erosion in children: a literature review. Pediatr Dent $2001 ; 23(1): 37-43$.

Linnett V, Seow WK, Connor F, Shepherd R. Oral health of children with gastroesophageal reflux disease: a controlled study. Aust Dent J 2002; 47(2): 156-162.

Luo Y, Zeng X, Du M, Bedi R. The prevalence of dental erosion in preschool children in China. J Dent 2005; 33(2): 115-121.

Lussi A. Erosive tooth wear - a multifactorial condition of growing concern and increasing knowledge. Monogr Oral Sci 2006; 20: 1-8.

Lussi A, Jaeggi T. Dental erosion in children. Monogr Oral Sci 2006; 20: 140-51.

Lussi A, Jaeggi T, Zero D. The role of diet in the aetiology of dental erosion. Caries Res 2004; 38(1): 34-44.

Mahoney EK, Kilpatrick NM. Dental erosion: part 1. Aetiology and prevalence of dental erosion. N Z Dent J 2003; 99(2): 33-41.

Mangueira DF, Sampaio FC, Oliveira AF. Association between socioeconomic factors and dental erosion in Brazilian schoolchildren. J Public Health Dent 2009; [Epub ahead of print] 
Mathew T, Casamassimo PS, Hayes JR. Relationship between sports drinks and dental erosion in 304 university athletes in Columbus, Ohio, USA. Caries Res 2002; 36: 281-87.

McGuire J, Szabo A, Jackson S, Bradley T, Okunseri C. Erosive tooth wear among children in the United States: relationship to race/ethnicity and obesity. Int $J$ Paediatr Dent 2009;19(2):91-8.

Millward A, Shaw L, Smith A. Dental erosion in four-year-old children from differing socioeconomic backgrounds. ASDC J Dent Child 1994; 61(4): 263-6.

Millward A, Shaw L, Smith AJ, Rippin JW, Harrington E. The distribution and severity of tooth wear and the relationship between erosion and dietary constituents in a group of children. Int J Paediatr Dent 1994; 4(3): 151-7.

Milosevic A, Young PJ, Lennon MA. The prevalence of tooth wear in 14-year-old school children in Liverpool. Community Dent Health 1994; 11: 83-86.

Ministério da Saúde. Sistema de Informação do Programa Nacional de Imunizações (SI-PNI). Campanha nacional de vacinação contra poliomielite dos municípios do estado de São Paulo - 14 de junho de 2008. Disponível em: URL:

http://pni.datasus.gov.br/consulta polio1 mun 08.asp?UF=35 [30 jun 2009].

Ministério da Saúde. Secretaria de Atenção à Saúde. Departamento de Ações Programáticas e Estratégicas. II Pesquisa de Prevalência de Aleitamento Materno nas Capitais Brasileiras e Distrito Federal/Ministério da Saúde, Secretaria de Atenção à Saúde, Departamento de Ações Programáticas e Estratégicas - Brasília: Editora do Ministério da Saúde, 2009. 108p.: il. - Série C. Projetos, Programas e Relatórios.

Monteiro CA, Conde WL. Tendência secular da desnutrição e da obesidade na infância na cidade de São Paulo (1974-1996). Rev Saúde Pública 2000; 34(6): 52 61. 
Moysés ST, Rodrigues CS. Ambientes saudáveis: uma estratégia de promoção de saúde bucal de crianças. In: Bönecker M, Sheiham A. Promovendo saúde bucal na infância e adolescência: conhecimentos e práticas - Cadernos de Odontopediatria. São Paulo: Livraria Editora Santos Ltda.; 2004. cap. 5, p.82.

Murakami, C; Corrêa, MSNP; Rodrigues, CRMD. Prevalência de erosão dental em crianças e adolescentes de São Paulo. UFES Revista de Odontologia 2006; v. 8: 4-9.

Nunn J, Gordon P, Morris A, Pine C, Walker A. Dental erosion -- changing prevalence? A review of British National children's' surveys. Int J Paediatr Dent 2003; 13(2):98-105.

O'Brien M. Children's dental health in the United Kingdom, 1993. London: OPCS. Her Majesty's Stationery Office 1994; 74-6, 113.

Oliveira, LB. Experiência de cárie dentária em crianças de 5 a 59 meses de idade e sua associação com fatores socioeconômicos e estado nutricional - Diadema, São Paulo [Tese de Doutorado]. São Paulo: Faculdade de Odontologia da USP; 2006.

OMS. Organização Mundial de Saúde. Levantamento epidemiológico de saúde bucal. São Paulo: Santos; 1999; p.65.

O'Sullivan EA, Curzon MEJ, Roberts GM, Milla PJ, Stringer MD.Gastroesophageal reflux in children and its relationship to erosion of primary and permanent teeth. Eur $\mathrm{J}$ Oral Sci 1998; 106:765-9.

Ohsuka K, Chino N, Nakagaki H, Kataoka I, Oshida Y, Ohsawa I et al. Analysis of risk factors for dental caries in infants: a comparison between urban and rural areas. Environ Health Prev Med 2009; 14: 103-10.

Pace F, Pallotta S, Tonini M, Vakil N, Bianchi Porro G. Systematic review: gastrooesophageal reflux disease and dental lesions. Aliment Pharmacol Ther 2008; 27(12): 1179-86. 
Peres K, Armênio M, Peres M, Traebert J, De Lacerda J. Dental erosion in 12-yearold schoolchildren: a cross-sectional study in Southern Brazil. Int J Paediatr Dent 2005; 15(4):249-55.

Pindborg JJ. Chemical and physical injuries. In: Pindborg JJ. Pathology of the dental hard tissues. Copenhagen: Munksgaard; 1970; 312-321.

Pinto VG. Identificação de problemas. In: Pinto VG. Saúde buccal coletiva. 4ª ed. São Paulo: Livraria Santos Editora Ltda., 2000. Cap.5; p.139-217.

Prefeitura de Diadema. Disponível em: URL: http://www.diadema.sp.gov.br [02 jul 2009].

Ramos-Gomez FJ, Weintraub JA, Gansky SA, Hoover CI, Featherstone JD. Bacterial, behavioral and environmental factors associated with early childhood caries. J Clin Pediatr Dent 2002; 26(2): 165-73.

Rios D, Magalhães A, Honório H, Buzalaf M, Lauris J, Machado M. The prevalence of deciduous tooth wear in six-year-old children and its relationship with potential explanatory factors. Oral Health Prev Dent 2007; 5(3):167-71.

Sabbah W, Tsakos G, Sheiham A, Watt RG. The role of health-related behaviors in the socioeconomic disparities in oral health. Soc Sci Med 2009; 68(2): 298-303.

Sanders AE, Slade GD, Turrell G, John Spencer A, Marcenes W. The shape of the socioeconomic-oral health gradient: implications for theoretical explanations. Community Dent Oral Epidemiol 2006; 34: 310-19.

SEADE. Sistema Estadual de Análise de Dados. Disponível em: URL: http://www.seade.gov.br. [02 jul 2009]

Shaw L, Smith A. Erosion in children: an increasing clinical problem? Dent Update 1994; 21(3): 103-106. 
Sheiham A, Bönecker M. Promoting children's oral health: theory and practice. Chicago; Quintessence; 2006.

Sherman PM, Hassall ER, Fagundes-Neto U, Gold BD, Kato S, Koletzko S, et al. A global, evidence-based consensus on the definitions of gastroesophageal reflux disease in the pediatric population. Am J Gastroenterol 2009; 104(5): 1278-95.

Smith BG, Knight JK. An index for measuring the wear of teeth. Br Dent J 1984; 156(12): 435-8.

Teixeira RM. Uma abordagem do cenário geral de sucos industrializados no contexto da alimentação saudável [Monografia de Especialização]. Brasília: Universidade de Brasília - Centro de Excelência em Turismo; 2007.

Tolia V, Vandenplas Y. Systematic review: the extra-oesophageal symptoms of gastro-oesophageal reflux disease in children. Aliment Pharmacol Ther 2009; 29(3): 258-72.

Truin G, van Rijkom H, Mulder J, van't Hof M. Caries trends 1996-2002 among 6and 12-year-old children and erosive wear prevalence among 12-year-old children in The Hague. Caries Res 2005; 39(1):2-8.

UNICEF. Fundo das Nações Unidas para a Infância. Situação da Infância Brasileira. 2006, p.220. Disponível em: URL: http://www.unicef.org/brazil/pt/IDI 2004.pdf [02 jul 2009].

Van Rijkom HM, Truin GJ, Frencken JE, König KG, van't Hof MA, Bronkhorst EM et al. Prevalence, distribution and background variables of smooth-bordered wear in teenagers in the Hague, the Netherlands. Caries Res 2002; 36(2): 147-54. 
Walker A, Gregory J, Bradnock G, Nunn J, White D. National Diet and Nutrition Survey: Young people aged 4 to 18 years. Vol.2: Report of the Oral Health Survey. TSO, London: HMSO, 2000.

Wasmer C, Pohl Y, Filippi A. Traumatic dental injuries in twins: is there a genetic risk for dental injuries? Dent Traumatol 2008; 24(6): 619-24.

Wiegand A, Müller J, Werner C, Attin T. Prevalence of erosive tooth wear and associated risk factors in 2-7-year-old German kindergarten children. Oral Dis 2006; 12(2):117-24.

Williams D, Croucher R, Marcenes W, O'Farrell M. The prevalence of dental erosion in the maxillary incisors of 14-year-old school-children living in Tower Hamlets and Hackney, London, UK. Int Dent J 1999; 49(4): 211-216.

WHO. World Health Organization. Expert Committee on Physical Status: the use and interpretation of anthropometry physical status. Geneva: World Health Organization; 1995. (WHO Techniques Report Series, v. 854).

WHO. Anthro 2005, Beta Version Feb $17^{\text {th }}$, 2006: Software for assessing growth and development of the world's children. Geneva: WHO, 2006a. Disponível em: URL: http://www.who.int/childgrowth/software/en/ [02 jul 2009].

WHO Child Growth Standards. The WHO Child Growth Standards Geneva: WHO, 2006b. Disponível em URL: http://www.who.int/childgrowth/en/ [02 jul 2009].

WHO. World Heatlh Organization (2003) ICD-10. Online Version. International statistical classification of diseases and related health problems.

World Health Organization (2007). International Classification of Diseases (ICD-10) Online - Version 2007. Chapter XI. Diseases of the digestive system (K00-K93) Diseases of the oral cavity, salivary glands and jaws (K00-K14). Disponível em: URL: http://apps.who.int/classifications/apps/icd/icd10online/ [14 set 2009]. 
WHO Oral health surveys: basic methods. 4 ed. Geneva: ORH/EPID, 1997.

Young A, Amaechi BT, Dugmore C, Holbrook P, Nunn J, Schiffner U, et al. Current erosion indices - flawed or valid? Summary. Clin Oral Invest 2008; 12(1): S59-S63.

Young WG, Khan F. Sites of dental erosion are saliva-dependent. J Oral Rehabil 2002; 29: 35-43.

Zardetto CGDC. Prevalência de cárie dentária em adolescentes residentes no município de São Paulo: indicadores de risco e gravidade [Tese de Doutorado]. São Paulo: Faculdade de Odontologia da USP; 2004. 


\title{
APÊNDICE A
}

\author{
Universidade de São Paulo \\ Faculdade de Odontologia
}

Termo de Consentimento Livre e Esclarecido

\section{"Levantamento Epidemiológico sobre as condições de saúde bucal de crianças de 12 a 59 meses de idade no município de Diadema - São Paulo"}

Pesquisador: Dra.Christiana Murakami

Orientador: Prof. Dr. Marcelo José Strazzeri Bönecker

Instituição/Departamento: Departamento de Ortodontia e Odontopediatria

Telefone para contato: (11) 3091-7854

Local da coleta de dados: Diadema

Objetivo do estudo: O objetivo desta pesquisa é de saber como é a distribuição de cárie, traumatismos dentários, maloclusões e erosão dental em crianças do município de Diadema.

Procedimentos: Um dentista irá realizar o exame bucal da criança usando um pequeno espelho, para verificar a presença de cárie, maloclusão (dente mal posicionado ou torto), erosão dental (desgaste) ou algum dente que sofreu trauma causado, por exemplo, por quedas ao andar ou correr, acidentes, etc. Algumas perguntas serão feitas sobre os dados pessoais e socioeconômicos da criança.

Benefícios: A partir dos dados colhidos, será possível identificar as necessidades de tratamento e realizar medidas educativas e preventivas para a população. Caso seja observada alguma necessidade de tratamento durante o exame clínico, a criança participante será encaminhada para tratamento odontológico.

Riscos: Como esta pesquisa se trata apenas de um exame odontológico e um questionário, não existe qualquer risco de ordem física ou psicológica previsto pela participação da criança.

Sigilo. As informações fornecidas por você serão confidenciais e de conhecimento apenas dos pesquisadores responsáveis. O pesquisador se compromete a manter o sigilo da identidade da criança.

A participação nesta pesquisa é voluntária e o responsável tem o direito de interromper o exame e não permitir que a criança participe da pesquisa. Tem também o direito de não responder as questões sobre dados pessoais da criança e dados socioeconômicos familiares sem sofrer qualquer penalização.

$$
\text { Eu, }
$$
portadora do R.G. como responsável pelo(a) menor , autorizo a participação dele(a) na pesquisa e atesto estar recebendo uma cópia deste termo.

Diadema, de de 2008 .

Responsável Legal pelo Participante

Marcelo J.S. Bönecker 


\title{
APÊNDICE B
}

\author{
FICHA CLÍNICA
}

Placa Bacteriana na Face Vestibular dos Incisivos: ( ) Presente ( ) Ausente

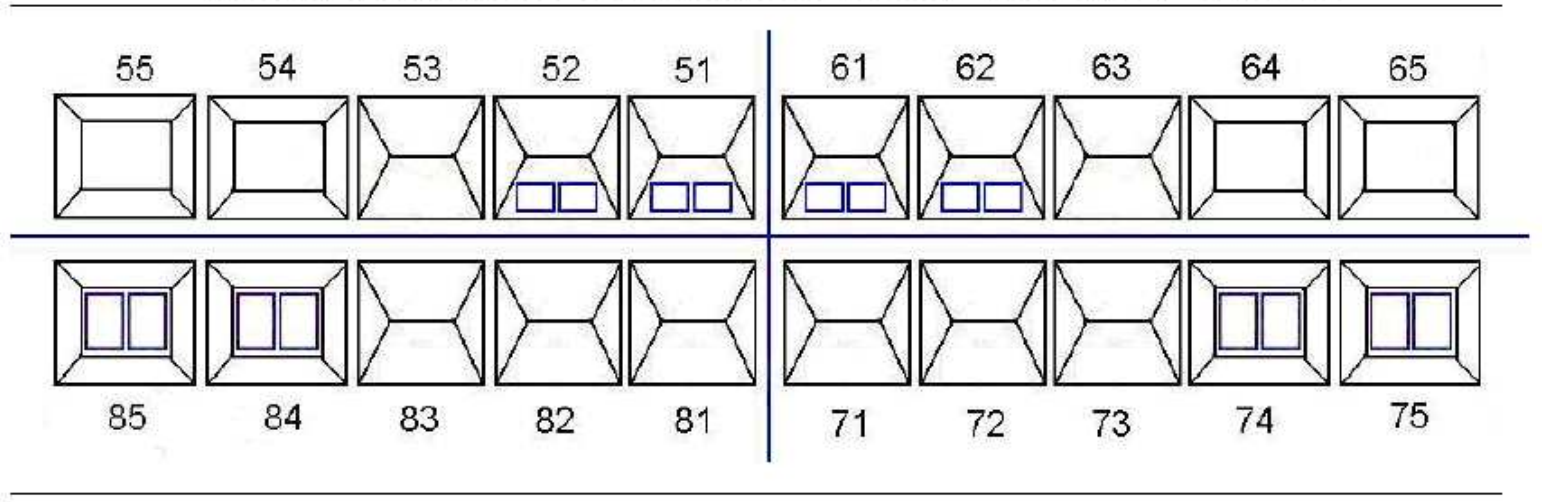

\begin{tabular}{|l|l|}
\hline \multicolumn{4}{|c|}{ Criança } \\
\hline Sexo: ( )F ( ) M $\quad$ Peso: Kg Altura: cm \\
Nascimento: I / Nasceu no ABCD: ( ) Sim ( ) Não \\
Mora com: ( ) mãe e pai ( ) mãe ( ) pai ( ) outros (ex. tios, avós) \\
( ) mãe e companheiro ( ) pai e companheira \\
Quantas pessoas moram na casa contando a criança? ( ) \\
Quantos cômodos tem a casa? ( ) \\
Casa própria? ( ) Sim ( ) Não \\
Familia mudou de casa no último ano? ( ) Sim ( ) Não \\
\hline
\end{tabular}

\begin{tabular}{|ll|}
\hline \multicolumn{3}{|c|}{ OCLUSÃO } \\
\hline Mordida aberta anterior & ( ) $\operatorname{Sim}$ ( ) Não \\
Mordida cruzada anterior & ( ) $\operatorname{Sim}$ ( ) Não \\
Mordida cruzada posterior & ( ) $\operatorname{Sim}$ ( ) Não \\
Sobressaliência acentuada & ( ) $\operatorname{Sim}$ ( ) Não \\
Selamento labial inadequado & ( ) $\operatorname{Sim}$ ( ) Não \\
\hline
\end{tabular}

\section{Mãe}

Idade: ( ) Quantos filhos tem? ( )

Estado civil? ( ) Solteira ( ) Casada ( ) Separada ( )Outro

Escolaridade: ( ) não estudou ( ) $1^{\circ} \mathrm{Grau}\left(\right.$ ) $2^{\circ} \mathrm{Grau}($ ) Universitário

Trabalho: ( ) Sim, o dia todo ( ) Sim, meio periodo ( ) Não

Ocupação: ( ) Salário Mensal: R\$

\begin{tabular}{|l|}
\hline Pai: Idade ( ) \\
\hline Escolaridade: ( ) não estudou ( ) $1^{\circ}$ Grau ( ) $2^{\circ}$ Grau ( ) Universitário \\
Trabalho: ( ) Sim, o dia todo ( ) Sim, meio período ( ) Não \\
Ocupação: ( ) Salário Mensal: R\$ \\
\hline
\end{tabular}

\begin{tabular}{|c|c|c|c|}
\hline \multicolumn{4}{|c|}{ TRAUMATISMO } \\
\hline & SIM & NÃO & DENTE \\
\hline \multicolumn{4}{|l|}{ Ausência de Dente } \\
\hline \multicolumn{4}{|l|}{ Fratura em Esmalte } \\
\hline \multicolumn{4}{|l|}{ Fratura em Dentina } \\
\hline \multicolumn{4}{|l|}{ Necessidade de tratamento } \\
\hline \multicolumn{4}{|l|}{ Qual? } \\
\hline \multicolumn{4}{|c|}{ Envolvimento Pulpar } \\
\hline & SIM & NÃO & DENTE \\
\hline \multicolumn{4}{|l|}{ Escurecimento da Coroa } \\
\hline \multicolumn{4}{|l|}{ Polpa exposta } \\
\hline Fistula & & & \\
\hline
\end{tabular}

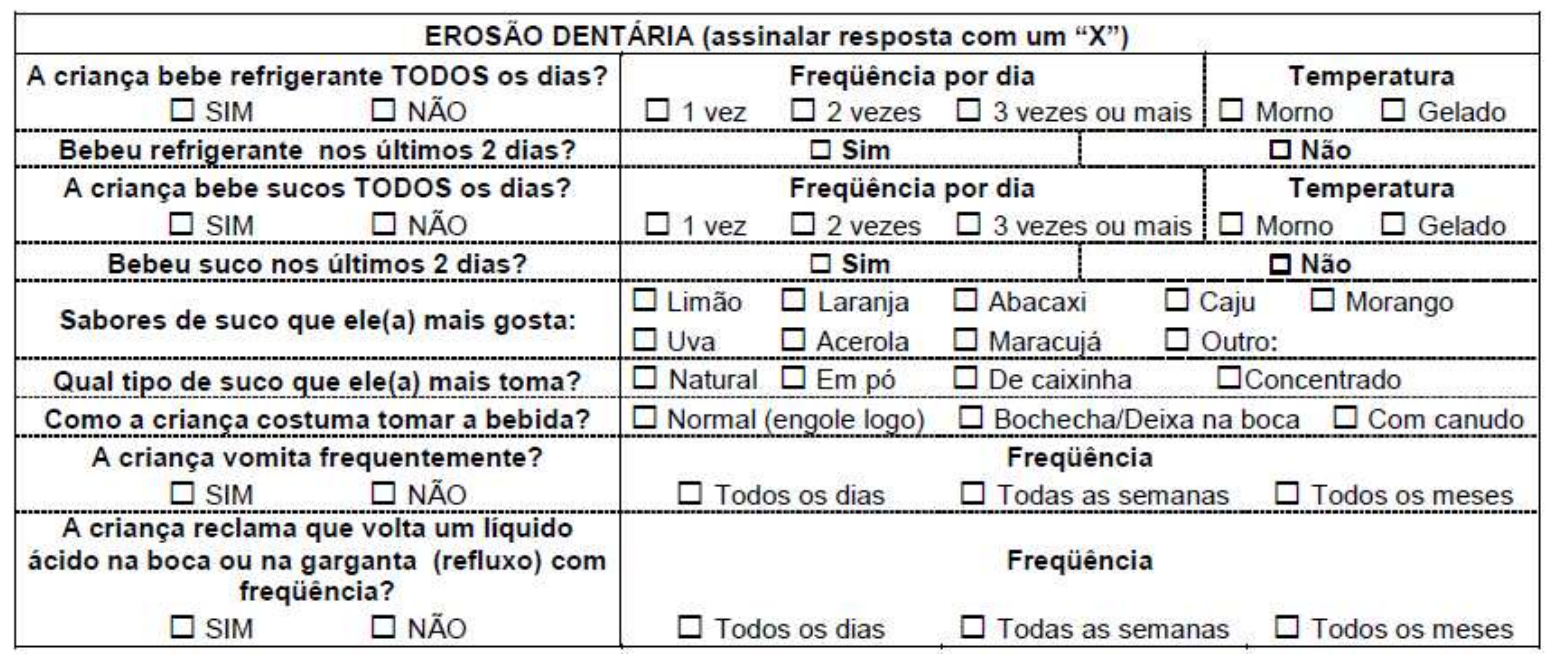




\section{ANEXO A}

Basic Erosive Wear Examination (BEWE) - BARTLETT; GANSS; LUSSI (2008)

\section{ESCORE}

$0 \quad$ Sem desgaste dental por erosão

1 Perda inicial da textura da superfície

$2^{*}$ Defeito distinto, perda de tecido duro em $<50 \%$ da área da superfície

$3^{*}$ Perda de tecido duro em $\geq 50 \%$ da área da superfície

${ }^{*}$ nos escores 2 e 3 a dentina está frequentemente afetada

\begin{tabular}{l|l|l|l|r}
\hline Escore mais alto & Escore mais alto & Escore mais alto & \\
$1^{\circ}$ sextante (17- & $2^{\circ}$ sextante $(13-$ & $3^{\circ}$ sextante $(24-$ & \\
$14)$ & $23)$ & $27)$ & \multirow{2}{*}{ Soma dos } \\
\hline Escore mais alto & Escore mais alto & Escore mais alto & escores \\
$4^{\circ}$ sextante (37- & $5^{\circ}$ sextante $(33-$ & $6^{\circ}$ sextante (44- & \\
$34)$ & $43)$ & $47)$ & \\
\hline
\end{tabular}




\section{ANEXO B}

\section{Índice de O’Brien (1994)}

\begin{tabular}{ll}
\hline \multicolumn{1}{c}{ PROFUNDIDADE } \\
\hline 0 & Normal (hígido) \\
\hline 1 & Somente em esmalte - perda da caracterização da superfície \\
\hline 2 & Em esmalte e dentina - perda de esmalte, expondo a dentina \\
\hline 3 & $\begin{array}{l}\text { Do esmalte à polpa - perda de esmalte e dentina resultando em exposição } \\
\text { pulpar }\end{array}$ \\
\hline 9 & Avaliação não pôde ser feita \\
\hline \multicolumn{2}{|c}{ ÁREA } \\
\hline 0 & Normal (hígido) \\
\hline 1 & Acometendo menos de $1 / 3$ da superfície \\
\hline 2 & Acometendo de $1 / 3$ a $2 / 3$ da superfície \\
\hline 3 & Acometendo mais de $2 / 3$ da superfície \\
\hline 9 & Avaliação não pôde ser feita \\
\hline
\end{tabular}




\section{ANEXO C}

Tabela de estudos sobre prevalência de erosão dentária em crianças pré-escolares.

\begin{tabular}{|c|c|c|c|c|c|}
\hline Ano & Referência & País & $\begin{array}{l}\text { Idade } \\
\text { (anos) }\end{array}$ & $\mathbf{n}$ & Prevalência (\%) \\
\hline 1994 & O'Brien & Reino Unido & $5-15$ & 17.061 & 5 anos: $52 \%$ \\
\hline 1994 & Millward; Shaw; Smith & Inglaterra & $4-5$ & 178 & 50 \\
\hline 1994 & Millward et al. & Inglaterra & $4-16,5$ & 101 & 100 \\
\hline 1995 & Hinds e Gregory & Grã Bretanha & $11 / 2-41 / 2$ & 1.522 & 19 \\
\hline 1995 & Jones e Nunn & Inglaterra & 3 & 135 & 29 \\
\hline 1995 & Downer & Reino Unido & $5-15$ & 4.210 & $\begin{array}{c}5 \text { anos: } 52 \%(\mathrm{P}) \text { e } \\
18 \%(\mathrm{~V}) ; 11 \text { anos: } 25 \%\end{array}$ \\
\hline 2000 & Walker et al. & Grã Bretanha & $4-6$ & 1.726 & 65 \\
\hline 2001 & Al-Malik; Holt; Bedi & Arábia Saudita & $2-5$ & 987 & 31 \\
\hline 2002 & $\begin{array}{c}\text { Al-Majed; Maguire; } \\
\text { Murray }\end{array}$ & Arábia Saudita & $5-6$ & 354 & 95 \\
\hline 2003 & Harding et al. & Irlanda & 5 & 202 & 47 \\
\hline 2003 & Chadwick e Pendry & Reino Unido & $5-15$ & 10.381 & $\begin{array}{c}5 \text { anos: } 53 \% \text { esmalte, } \\
22 \% \text { dentina/polpa }\end{array}$ \\
\hline 2004 & Deshpande e Hugar & Índia & $5-6$ & 100 & $\begin{array}{l}5 \text { anos: } 28,6(n=35), \\
6 \text { anos: } 30,7(n=65)\end{array}$ \\
\hline 2005 & Luo et al. & China & $3-5$ & 1.949 & 5,7 \\
\hline 2006 & Wiegand et al. & Alemanha & $2-7$ & 463 & 32 \\
\hline 2007 & Kazoullis et al. & Austrália & $5,5-14,6$ & 714 & 68 \\
\hline
\end{tabular}


ANEXO D

\author{
Universidade de São Paulo \\ Faculdade de Odontologia \\ Comitê de Ética em Pesquisa
}

\title{
PARECER DE APROVAÇÃO
}

Protocolo 19/2008

Com base em parecer de relator, o Comitê de Ética em

Pesquisa APROVOU 0 protocolo de pesquisa "LEVANTAMENTO EPIDEMIOLÓGICO SOBRE AS CONDIÇÕES DE SAÚdE BUCAL DE CRIANÇAS DE 5 A 59 MESES DE IDADE NO MUNICIPIO DE DIADEMA SÃO PAULO", de responsabilidade da Pesquisadora CHRISTIANA MURAKAMI e sob orientação do Prof. Dr. MARCELO JOSÉ STRAZZERI BÖNECKER.

Tendo em vista a legislação vigente, devem ser encaminhados a este Comitê relatórios anuais referentes ao andamento da pesquisa e ao término cópia do trabalho em "cd". Qualquer emenda do projeto original deve ser apresentada a este CEP para apreciação, de forma clara e sucinta, identificando a parte do protocolo a ser modificada e suas justificativas.

São Paulo, 12 de maio de 2008.

Prof. Dr. João Gualberto de Cerqueira Ruz Coordenador do CEP-FOUSP 


\section{ANEXO E}

\section{TERMO DE ANUENCIA}

Autorizo a pesquisadcra Christiana Murakami a efetuar pesquisa de campo com coleta de dados durante a primera fase da campanha de vacinação contra a poliomielite do municipio de Diadema do ano de 2008. como projeto de pesquisa para obtençāo do título de mestre. sob a orientaçāo do Prcf. Dr. Marcelo José Strazzeri Bönecker do Deparamento de Odontopediatria da Faculdade de Cdontologia da Universidade de São Paulo com o titulo "Levantamento Epidemiológico sobre as condiçôes de saúde bucal de crianças de 5 a 59 meses do municipio de Diadema - São Paulo".

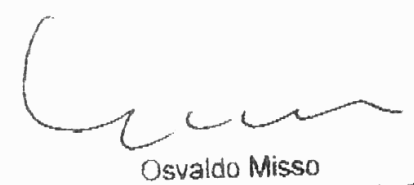

Secretário de Saúde do Municipio de Diadema 